\title{
Organic carbon and total nitrogen stocks in soils of the Lena River Delta
}

\author{
S. Zubrzycki ${ }^{1}$, L. Kutzbach ${ }^{1}$, G. Grosse ${ }^{2}$, A. Desyatkin ${ }^{3}$, and E.-M. Pfeiffer ${ }^{1}$ \\ ${ }^{1}$ Institute of Soil Science, KlimaCampus, University of Hamburg, Hamburg, Germany \\ ${ }^{2}$ Geophysical Institute, University of Alaska Fairbanks, Fairbanks, Alaska, USA \\ ${ }^{3}$ Institute for Biological Problems of Cryolithozone, SB RAS, Yakutsk, Russia
}

Correspondence to: S. Zubrzycki (s.zubrzycki@ifb.uni-hamburg.de)

Received: 14 November 2012 - Published in Biogeosciences Discuss.: 6 December 2012 Revised: 18 April 2013 - Accepted: 30 April 2013 - Published: 3 June 2013

\begin{abstract}
The Lena River Delta, which is the largest delta in the Arctic, extends over an area of $32000 \mathrm{~km}^{2}$ and likely holds more than half of the entire soil organic carbon (SOC) mass stored in the seven major deltas in the northern permafrost regions. The geomorphic units of the Lena River Delta which were formed by true deltaic sedimentation processes are a Holocene river terrace and the active floodplains. Their mean SOC stocks for the upper $1 \mathrm{~m}$ of soils were estimated at $29 \mathrm{~kg} \mathrm{~m}^{-2} \pm 10 \mathrm{~kg} \mathrm{~m}^{-2}$ and at $14 \mathrm{~kg} \mathrm{~m}^{-2} \pm 7 \mathrm{~kg} \mathrm{~m}^{-2}$, respectively. For the depth of $1 \mathrm{~m}$, the total SOC pool of the Holocene river terrace was estimated at $121 \mathrm{Tg} \pm 43 \mathrm{Tg}$, and the SOC pool of the active floodplains was estimated at $120 \mathrm{Tg} \pm 66 \mathrm{Tg}$. The mass of SOC stored within the observed seasonally thawed active layer was estimated at about $127 \mathrm{Tg}$ assuming an average maximum active layer depth of $50 \mathrm{~cm}$. The $S O C$ mass which is stored in the perennially frozen ground at the increment $50-100 \mathrm{~cm}$ soil depth, which is currently excluded from intense biogeochemical exchange with the atmosphere, was estimated at $113 \mathrm{Tg}$. The mean nitrogen $(\mathrm{N})$ stocks for the upper $1 \mathrm{~m}$ of soils were estimated at $1.2 \mathrm{~kg} \mathrm{~m}^{-2} \pm 0.4 \mathrm{~kg} \mathrm{~m}^{-2}$ for the Holocene river terrace and at $0.9 \mathrm{~kg} \mathrm{~m}^{-2} \pm 0.4 \mathrm{~kg} \mathrm{~m}^{-2}$ for the active floodplain levels, respectively. For the depth of $1 \mathrm{~m}$, the total $\mathrm{N}$ pool of the river terrace was estimated at $4.8 \mathrm{Tg} \pm 1.5 \mathrm{Tg}$, and the total $\mathrm{N}$ pool of the floodplains was estimated at $7.7 \mathrm{Tg} \pm 3.6 \mathrm{Tg}$. Considering the projections for deepening of the seasonally thawed active layer up to $120 \mathrm{~cm}$ in the Lena River Delta region within the 21st century, these large carbon and nitrogen stocks could become increasingly available for decomposition and mineralization processes.
\end{abstract}

\section{Introduction}

Degradation of permafrost is affected by climate change (e.g., Grosse et al., 2011; Romanovsky et al., 2010), but also results in important feedbacks to climate change (e.g., Schuur et al., 2009; Schaefer et al., 2011). Therefore, the characterisation of permafrost-underlain areas, permafrostaffected soils, and their soil organic carbon (SOC) and nitrogen $(\mathrm{N})$ stocks are important for understanding interactions of the biogeochemical cycle with global climate. The area occupied by permafrost-affected soils amounts to more than 8.6 million $\mathrm{km}^{2}$, which is about $27 \%$ of all land areas north of $50^{\circ} \mathrm{N}$ (Jones et al., 2010). Enormous amounts of organic matter have accumulated in permafrost-affected soils during the Quaternary period (Harden et al., 1992; Smith et al., 2004; Zimov et al., 2006; Gorham et al., 2007; Schirrmeister et al., 2011). Recent estimates show that today there might be up to $496 \mathrm{Pg}\left(1 \mathrm{Pg}=10^{15} \mathrm{~g}\right)$ of SOC stored within the uppermost one metre of the permafrost-affected soils (Tarnocai et al., 2009). Although the area occupied by the main arctic deltas as indicated by Walker (1998) amounts only to $77000 \mathrm{~km}^{2}$ (total area of arctic and alpine tundra: $7.4 \times$ $10^{6} \mathrm{~km}^{2}$ according to Loveland et al., 2000), their contribution to the total SOC pool within the permafrost-underlain areas is high (Tarnocai et al., 2009) due to the large thickness of their deposits resulting from typical river deltaic sedimentation and accumulation processes (e.g., Schwamborn et al., 2002). Permafrost-affected soils are expected to undergo fundamental property changes due to the observed and projected climate changes (Koven et al., 2011), including higher decomposition rates of organic matter and increased 


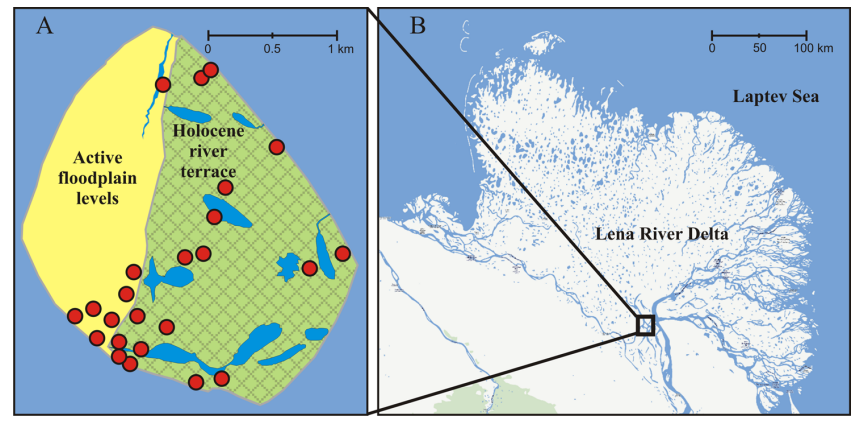

Fig. 1. (A) Map of Samoylov Island with locations of study sites. (B) The investigation area in the Lena River Delta in northeast Siberia with the location of Samoylov Island (Map B based on Google and Geocentre Consulting 2011).

release of the greenhouse gases carbon dioxide and methane to the atmosphere (Dutta et al., 2006; Wagner et al., 2007; Khvorostyanov et al., 2008; Schuur et al., 2008, 2009; Grosse et al., 2011). Thus, permafrost-affected soils have to be considered as a globally important element of the cryosphere within the global climate system. The majority of published articles on element stocks in permafrost-affected soils focuses on the North American region. In recent years, however, some areas of the Eurasian permafrost - especially in the Russian region - have also been increasingly studied (Kolchugina et al., 1995; Matsuura and Yefremov, 1995; Chestnyck et al., 1999; Stolbovoi et al., 2006; Gundelwein et al., 2007; Hugelius and Kuhry, 2009).

Most previous studies analysed carbon pools of specific regions or components of permafrost-affected soil carbon pools (e.g., Stolbovoi, 2002; Tarnocai et al., 2003; Zimov et al., 2006; Ping et al., 2008; Bliss and Maursetter, 2010; Schirrmeister et al., 2011), resulting in the overall challenge to compare and combine the different regional assessments, including soil type/order-specific SOC pools and pools calculated over various depths. First important steps towards unification in mapping the distribution of soil types and soil carbon stocks were achieved by assembling the Soil Atlas of the Arctic (Jones et al., 2010) and a new pan-arctic estimate of SOC pools in permafrost regions (Tarnocai et al., 2009). These studies suggest that the total SOC pool of the permafrost-affected soils to $3 \mathrm{~m}$ depth is very high at $1024 \mathrm{Pg}$ (Tarnocai et al., 2009), exceeding the carbon pools within the entire global vegetation biomass $(650 \mathrm{Pg})$ or the atmosphere $(750 \mathrm{Pg})$ (IPCC, 2007). However, despite this improved quantification, SOC data for the huge areas of Siberia are still scarce, uncertainties are high, and more detailed landscape-scale assessments are necessary (Tarnocai et al., 2009; Zubrzycki et al., 2012).

Here, we focus on the assessment of soil organic carbon and total nitrogen pools in the Northeast-Siberian Lena River Delta. The area that the Lena River Delta occupies amounts to $42 \%$ of the total area of all arctic deltas. Analysing the GIS-Polygons of the Northern Circumpolar Soil Carbon Database (Hugelius et al., 2013) corresponding to the spatial extent of the Lena River Delta, the SOC pool of this delta for the depth of $1 \mathrm{~m}$ can be estimated to be around $670 \mathrm{Tg}$ carbon. While the Lena River Delta consists of various geomorphic units, including some of non-deltaic origin (Schwamborn et al., 2002), our study concentrates on the element stocks of soils in areas of Holocene deltaic sedimentation, in particular the Holocene river terrace and the active floodplains. The first goal of the study was a detailed quantification of the SOC as well as the N stocks of the different soil units on Samoylov Island, located in the southern-central Lena River Delta. Of special interest in this region were the rarely investigated currently perennially frozen layers from $50 \mathrm{~cm}$ up to $100 \mathrm{~cm}$ depth. Samoylov Island is composed of two geomorphic parts that are regarded to be representative for the Holocene river terrace and the active floodplains within the Lena River Delta, respectively. The second goal was to upscale the results from Samoylov Island across the correspondent soil-covered areas of the Holocene river terrace and the floodplains within the Lena River Delta using remote-sensing data (Landsat-7 ETM+ and WorldView-1) and to estimate the SOC and the total N pools for these areas.

\section{Study area}

Our study site is located on Samoylov Island $\left(72^{\circ} 22^{\prime} \mathrm{N}\right.$, $\left.126^{\circ} 30^{\prime} \mathrm{E}\right)$ situated at one of the main Lena River channels, the Olenyokskaya Channel in the southern central part of the Lena River Delta, about $180 \mathrm{~km}$ south of the coast of the Arctic Ocean (Fig. 1). At around $32000 \mathrm{~km}^{2}$ (Are et al., 2000), the Lena River Delta is the largest arctic delta. It is located in north-eastern Siberia, where the Lena River cuts through the Verkhoyansk Mountains and discharges into the Laptev Sea, a part of the Arctic Ocean.

The Lena River Delta consists of three main geomorphic terrace-like units and the modern floodplain levels (Grigoriev, 1993; Schwamborn et al., 2002). Only the youngest river terrace and the modern floodplains are of Holocene deltaic origin, while the second and third terracelike units are largely of pre-Holocene age and have a different composition and genesis (Schwamborn et al., 2002). Within this study, only the two Holocene deltaic units were sampled.

Samoylov Island is part of this Holocene delta and consists of two major geomorphic parts (Akhmadeeva et al., 1999) (Fig. 1a) which vary in sedimentary composition as well as contents of organic matter in the soils. The western part of Samoylov Island is represented by a modern floodplain up to $5 \mathrm{~m}$ above sea level (a.s.l.) which is flooded annually in spring. The eastern part of the island consists of an elevated (10-16 m a.s.l.) river terrace of Late Holocene age (Pavlova and Dorozhkina, 1999). Between these two units, there is a distinct and sharp step of about $5 \mathrm{~m}$ (Kutzbach, 2006). The river terrace is flooded only during extreme flooding events 

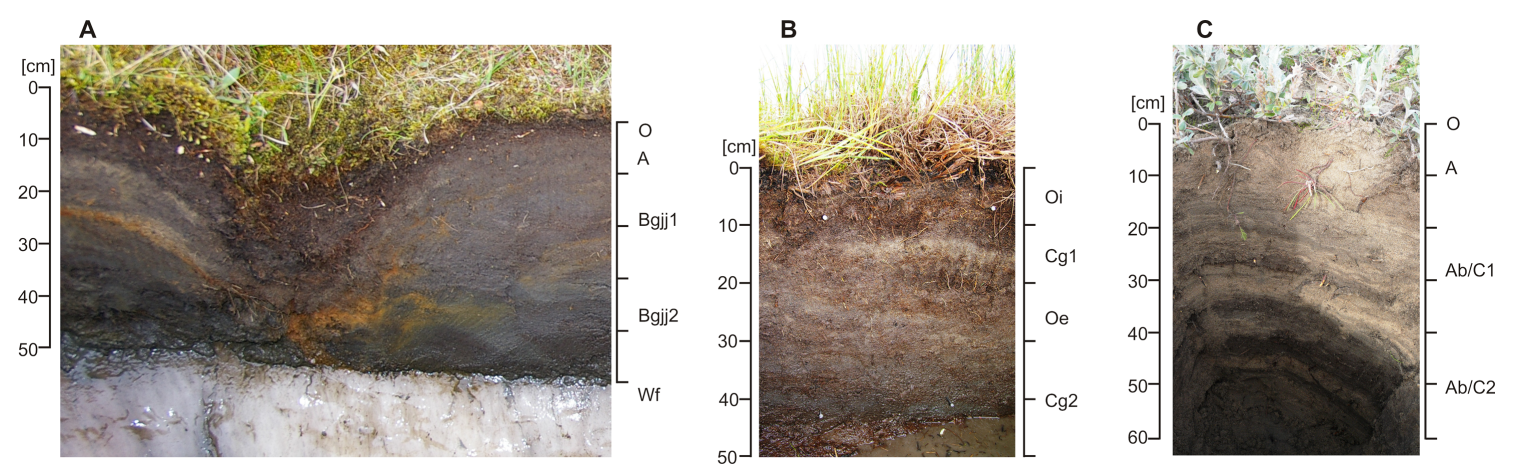

Fig. 2. Representative soil types dominating Samoylov Island. (A) Glacic Aquiturbel, a cryoturbated permafrost-affected soil with redox depletions and aquic conditions as well as a glacic layer within $100 \mathrm{~cm}$ of the mineral soil surface. (B) Typic Historthel, a non-cryoturbated permafrost-affected soil that have in $30 \%$ or more of the pedon organic soil material. (C) Psammentic Aquorthel, a non-cryoturbated sanddominated permafrost-affected soil with redox depletions and aquic conditions during normal years. Soil classification according to the US Soil Taxonomy (Soil Survey Staff, 2010). Photograph of Psammentic Aquorthel: courtesy of Tina Sanders.

Table 1. Selected exemplary soil chemical properties of three representative soil types dominating Samoylov Island (see also Fig. 2). Gravimetric contents of organic carbon $(\mathrm{OC})$ and total nitrogen $(\mathrm{N})$ are expressed as percentages.

\begin{tabular}{lrrrrrrrrrrrrr}
\hline & \multicolumn{3}{c}{ Glacic Aquiturbel } & \multicolumn{4}{c}{ Typic Historthel } & \multicolumn{3}{c}{ Psammentic Aquorthel } \\
\hline $\begin{array}{l}\text { Horizons } \\
\text { Properties }\end{array}$ & $\mathrm{O}$ & $\mathrm{A}$ & $\mathrm{Bg} 1$ & $\mathrm{Bg} 2$ & $\mathrm{Oi}$ & $\mathrm{Cg} 1$ & $\mathrm{Oe}$ & $\mathrm{Cg} 2$ & $\mathrm{O}$ & $\mathrm{A}$ & $\mathrm{Ab} / \mathrm{C} 1$ & $\mathrm{Ab} / \mathrm{C} 2$ \\
& & & & & & & & & & & & \\
\hline OC (\%) & 12.42 & 1.63 & 2.32 & 2.18 & 24.48 & 3.02 & 9.48 & 7.24 & 5.89 & 1.65 & 0.92 & 0.75 \\
$\mathrm{~N}(\%)$ & 0.72 & 0.04 & 0.11 & 0.09 & 0.87 & 0.08 & 0.21 & 0.18 & 0.19 & 0.09 & 0.06 & 0.05 \\
$\mathrm{pH}$ & 6.5 & 6.8 & 6.2 & 5.6 & 6.5 & 6.7 & 6.2 & 6.2 & 6.5 & 7.3 & 7.2 & 7.1 \\
\hline
\end{tabular}

(Schwamborn et al., 2002). This Holocene river terrace is characterised by ice wedge polygons with wet sedge tundra vegetation. Polygonal structures imply micro-scale variability in the topography with polygonal centres and polygonal rims. The rims generally are elevated and characterised by pronounced cryoturbation. The centres can be of different quality depending of the development stage (French, 2007). Low-centred polygons have depressed centres with high water saturation during the summer months. High-centred polygons are characterised by elevated centres and are drier compared to the centres of low-centred polygons. The soils of Samoylov Island are Orthels and Turbels (Pfeiffer et al., 2000, 2002; Boike et al., 2012) according to the US Soil Taxonomy (Soil Survey Staff, 2010). The Soil Complex Glacic Aquiturbel/Typic Historthel dominates the Holocene river terrace (Fig. 2, Table 1) (Fiedler et al., 2004; Kutzbach et al., 2004) and is characterised by ice wedge polygons. The sandy active floodplain is dominated by Psammentic Aquorthels (Fig. 2, Table 1) (Pfeiffer et al., 2002). Furthermore, there are Psammorthels and Fibristels with different subgroups distributed over the island (Sanders et al., 2010). Mean maximum active layer thickness at the river terrace currently is about $50 \mathrm{~cm}$ in August (Boike et al., 2012). Thaw depths are larger on the floodplain.
These two geomorphic units found on Samoylov Island are also widespread in the Lena River Delta and dominate the northern, eastern and central delta. In the western delta, Ulrich et al. (2009) studied the surface-spectral and soil characteristics of geomorphic units and also separated a Holocene river terrace and the active floodplains from the second and third main geomorphic terrace. Soil characteristics and active layer depths in their study are similar to those found on Samoylov Island. Morgenstern et al. (2008) estimated the combined area of the Holocene river terrace and the active floodplain levels at $55 \%$ of the Lena River Delta area.

The investigation area is dominated by an arctic-subarctic climate with continental influence and is characterised by low temperatures and low precipitation. The mean annual air temperature, measured at the climate reference site in Tiksi $\left(71^{\circ} 41^{\prime} \mathrm{N}, 128^{\circ} 42^{\prime} \mathrm{E}\right)$, which is located about $110 \mathrm{~km}$ southeast from Samoylov Island, was $-13.5^{\circ} \mathrm{C}$, and the mean annual precipitation was $323 \mathrm{~mm}$ during the $30 \mathrm{yr}$ period $1961-$ 1990 (Roshydromet, 2011). The average temperature of the warmest month (August) was $7.1{ }^{\circ} \mathrm{C}$, whereas the coldest month is January with $-32.4{ }^{\circ} \mathrm{C}$ (Roshydromet, 2011) indicating an extreme seasonal temperature amplitude typical for continental polar regions. Data derived from the meteorological station on Samoylov Island indicated a mean annual air temperature of $-12.5^{\circ} \mathrm{C}$ from $1998-2011$ and a low mean 
annual rainfall (liquid precipitation) of around $125 \mathrm{~mm}$ for years 1999-2011 (Boike et al., 2012).

The region is underlain by deep continuous permafrost of 400-600 m thickness (Grigoriev, 1960; Yershov et al., 1991).

\section{Methods}

\subsection{Soil coring and sampling}

For this study, a portable permafrost auger set was used to obtain shallow undisturbed cores of frozen ground material. The set consisted of an engine power head (STIHL BT 121, Andreas Stihl AG \& Co. KG) and a Snow-Ice-PermafrostResearch-Establishment (SIPRE) coring auger (Jon's Machine Shop, Fairbanks, Alaska) originally designed by the Cold Region Research and Engineering Laboratory (CRREL). We collected 37 frozen cores of minimum $1 \mathrm{~m}$ length in April and May 2011 (Zubrzycki, 2012). Four cores were excluded from further analysis because they did not match our quality requirements. These requirements were that the length of the undisturbed sample should be $\geq 1 \mathrm{~m}$ and that the sample site was not a water-filled polygon. The remaining frozen cores were subsampled immediately in the field laboratory due to the logistical limits for sample weight. We sliced six $(i=1,2, \ldots, 6)$ cylindrical samples (each with a volume of approximately $92 \mathrm{~cm}^{3}$ ) of each of the cores from the following depths: $0-2 \mathrm{~cm}(i=1), 8-10 \mathrm{~cm}(i=2), 28$ $30 \mathrm{~cm}(i=3), 48-50 \mathrm{~cm}(i=4), 73-75 \mathrm{~cm}(i=5)$, and 98 $100 \mathrm{~cm}(i=6)$. These depths were selected to get detailed information of the depth distribution of the SOC and N pools within the first metre of ground. The depth of $2 \mathrm{~cm}$ and $10 \mathrm{~cm}$ were selected to detect differences in SOC and N pools of the youngest soil accumulation. The depth of $30 \mathrm{~cm}$ was selected for comparison with literature citing this special depth (e.g., Stolbovoi, 2002; Hugelius et al., 2010; Zubrzycki et al., 2012) as well as the depth of $100 \mathrm{~cm}$ (e.g., Post et al., 1982; Ping et al., 2008; Tarnocai et al., 2009; Bliss and Maursetter, 2010). $50 \mathrm{~cm}$ was the mean maximum active layer thickness in August and was selected to clearly differentiate between the active and perennially frozen layer. The depth of $75 \mathrm{~cm}$ was selected to have additional information for the perennially frozen layer between the depths of $50 \mathrm{~cm}$ and $100 \mathrm{~cm}$.

\subsection{Soil analyses}

The gravimetric contents of organic carbon $c_{\mathrm{OC}}$ and total $\mathrm{N}$ $c_{\mathrm{N}}$ were analysed with an element analyser based on high temperature combustion and subsequent gas analysis (Vario MAX CNS, Elementar Analysesysteme GmbH, Germany) using oven-dried $\left(12 \mathrm{~h}\right.$ at $\left.105^{\circ} \mathrm{C}\right)$ and ground samples (ISO $10694,1995)$. The bulk density $\left(\rho_{\mathrm{d}}\right)$ was calculated as the ratio of the dry mass of an undisturbed soil sample and the volume of a cylindrical sample of a core with a height of $20 \mathrm{~mm}$ and the diameter of $76 \mathrm{~mm}$. There were no coarse fragments $>2 \mathrm{~mm}$ in any of the undisturbed soil samples.
The volumetric ice contents were calculated using the determined gravimetric ice contents (drying soils at $65^{\circ} \mathrm{C}$ for 2 days and measuring the frozen-fresh sample mass before and the dry sample mass after drying) and the specific ice density of $0.9167 \mathrm{~g} \mathrm{~cm}^{-3}$ at $0^{\circ} \mathrm{C}$.

\subsection{Organic carbon and total nitrogen stock calculations}

The volumetric contents of SOC $\rho_{\mathrm{OC}}$ and total $\mathrm{N} \rho_{\mathrm{N}}$ (both in $\mathrm{kg} \mathrm{m}^{-3}$ ) of the 2-cm soil layers were calculated as

$\rho_{\mathrm{OC}}=c_{\mathrm{OC}} \cdot \rho_{\mathrm{d}}$

and

$\rho_{\mathrm{N}}=c_{\mathrm{N}} \cdot \rho_{\mathrm{d}}$

where $c_{\mathrm{OC}}$ and $c_{\mathrm{N}}$ are the gravimetric contents of organic carbon and total $\mathrm{N}$, and $\rho_{\mathrm{d}}$ is the bulk density. For the estimation of the SOC and total N stocks over specific soil depths, volumetric contents of SOC and total N of the non-sampled soil layers between the $2-\mathrm{cm}$ soil layers that were sampled and analysed were estimated by linear interpolation in 1-cm intervals. Stocks of SOC $S_{\mathrm{OC}}\left(h_{\mathrm{r}}\right)$ and total N $S_{\mathrm{N}}\left(h_{\mathrm{r}}\right)$ over different reference depths $h_{\mathrm{r}}$ were then calculated by integrating the volumetric contents of organic carbon and total $\mathrm{N}$ over soil depth $h$ from the soil surface $(0 \mathrm{~cm})$ to the respective reference depths $h_{\mathrm{r}}$ as:

$S_{\mathrm{OC}}\left(h_{\mathrm{r}}\right)=\int_{0 \mathrm{~cm}}^{h_{\mathrm{r}}} \rho_{\mathrm{OC}} \mathrm{d} h$

and

$S_{\mathrm{N}}\left(h_{\mathrm{r}}\right)=\int_{0 \mathrm{~cm}}^{h_{\mathrm{r}}} \rho_{\mathrm{N}} \mathrm{d} h$

where the following reference depths $h_{\mathrm{r}}$ were chosen: $2 \mathrm{~cm}$, $10 \mathrm{~cm}, 30 \mathrm{~cm}, 50 \mathrm{~cm}, 75 \mathrm{~cm}, 100 \mathrm{~cm}$.

\subsection{Synthesis of existing soil information}

In addition to investigating the general SOC stocks of Samoylov Island based on our new core data and a characterisation of morphological units on this island, we also synthesized existing soil data from Samoylov Island mapped during previous expeditions (Pfeiffer et al., 2000, 2002). Prior to reanalysing the Samoylov soil data we updated the existing soil map (Pfeiffer et al., 2000; Sanders et al., 2010; Zubrzycki et al., 2012) for Samoylov Island with the extent of the island shape in August 2010 (Fig. 1). This was necessary due to the dynamic geomorphic processes occurring within the central Lena River Delta. For example, we observed high erosion rates in the south eastern and pronounced accumulations rates in the western part of the island. 


\subsection{Organic carbon and total nitrogen pool calculations}

For the calculation of the SOC and N pools for the two geomorphologic units investigated on Samoylov Island, upscaling of the $S_{\mathrm{OC}}$ and $S_{\mathrm{N}}$ stocks of all investigated reference depths was performed by multiplying the means of $S_{\mathrm{OC}}$ and $S_{\mathrm{N}}$ of all those depths by the estimated areas of the two geomorphologic units, the Holocene river terrace and the active floodplain levels, respectively.

\subsection{Satellite data and image processing}

\subsubsection{Image data and processing}

A Landsat image mosaic covering more than $98 \%$ of the delta was used to determine the extent of the Holocene river terrace and the active floodplains. The mosaic was generated from three Landsat-7 ETM+ satellite images taken during the summer on 27 July 2000 (path 131, row 8 and 9) and on 26 July 2001 (path 135, row 8). A detailed description of the image processing, atmospheric corrections, image co-referencing and mosaicking is provided by Schneider et al. (2009). The final mosaic has a spatial resolution of $30 \mathrm{~m}$, encompasses the multispectral Landsat-7 bands 1-5 and 7 , and has a horizontal accuracy of about $50 \mathrm{~m}$.

The areas of the sand-rich Arga Complex belonging to the 2nd main geomorphic unit in the Lena River Delta, and the Yedoma islands of the 3rd main geomorphic unit were not considered in our study of the Holocene and active delta portions. Therefore, we removed these areas by clipping with a mask based on geographic information system layers provided by Morgenstern et al. (2008) and Morgenstern et al. (2011), who delineated the extent of the Lena River Delta terraces manually from the same Landsat image mosaic under inclusion of cryostratigraphic and geologic field knowledge. In addition, we masked the sandy barrier islands offshore the western delta and the mountainous mainland areas along the southern delta boundary.

For accuracy assessment of our classification of the Holocene river terrace and the active floodplains, we used multiple WorldView-1 images (panchromatic band, $0.5 \mathrm{~m}$ ground resolution) from three different delta portions as independent high-resolution datasets from which we visually interpreted land unit type. The images were acquired during the snow-free seasons of 2009 (26 September and 7 August) and 2011 (11 June). The images have a geolocation accuracy better than the Landsat pixel size. For all processing steps we used ArcGIS 10 (ESRI).

\subsubsection{Supervised classification}

As a result of prior knowledge of the investigated area based on personal field experience, a supervised classification technique was selected. Based on our field knowledge, we were able to set up training areas for the classification and assign them to a class category. Specifically, we created ten training sample areas per target geomorphic unit in the Lena River Delta. Based on general geomorphic classifications of the Lena River Delta by Grigoriev (1993), the target units for our image classification were (1) the Holocene river terrace, (2) the active floodplains, and (3) the water bodies, all of which are spectrally largely dissimilar. We then performed a Maximum Likelihood Classification with the training sample areas using all available multispectral bands $1-5$ and 7 of the Landsat-7 ETM+ images.

\subsubsection{Post-classification imagery processing}

A post-classification generalization of the results was performed in ArcGIS. After grouping connected pixels of the same class into regions we merged isolated pixels surrounded entirely by pixels of a different class with that class. Lastly we re-assigned class identity for pixels in regions consisting of less than four pixels to identify and assign the most appropriate class for such pixels from its nearest neighbours (ArcGIS Resource Center, 2012). We next excluded all water bodies $>3600 \mathrm{~m}^{2}$ (4 Landsat pixels) from the satellite imagery of the Lena River Delta for later upscaling over soilcovered areas only. Additionally, we corrected the extent of the Holocene river terrace's soil-covered area reducing it by the percentage of small water ponds and troughs (14\%) detected by high-resolution aerial photography for Samoylov Island (Sachs et al., 2010).

\subsubsection{Accuracy assessment of the classifications}

Within the footprint of the WorldView-1 images that overlapped with delta portions, we randomly selected 150 points in the delta regions covered by our three main classes (water, Holocene terrace, active floodplain) (Fig. 3). Both Holocene terrace and active floodplains are clearly differentiated in their characteristics in these high resolution images. While the active floodplain areas do not have any relief and any ice wedge polygonal structures, the Holocene river terrace shows well developed ice wedge polygons. For all points we first visually interpreted the dominant land unit within a $10 \mathrm{~m}$ circular buffer from WorldView-1 data and then extracted the class from our Landsat classification for direct comparison. Data points were then cross-tabulated and classification accuracy for all investigated classes calculated according to Congalton (1991).

\subsection{Statistics}

Descriptive statistics, correlation analyses as well as analyses of variances (response variables: $c_{\mathrm{OC}}$ and $c_{\mathrm{N}}$; samples: river terrace, floodplain) for soil data were performed using the SPSS package version 16.0.1. 
Table 2. Bulk densities for all six investigated soil layers at different depths and both geomorphic units, the Holocene river terrace and the active floodplain levels, expressed in $\mathrm{g} \mathrm{cm}^{-3}$ with the mean values and the respective standard deviations (SD) as well as the minima (Min.) and maxima (Max.).

\begin{tabular}{|c|c|c|c|c|c|c|c|c|}
\hline & \multicolumn{4}{|c|}{ Holocene River Terrace } & \multicolumn{4}{|c|}{ Active Floodplain Levels } \\
\hline \multirow[t]{2}{*}{$\begin{array}{l}\text { Soil depth } \\
(\mathrm{cm})\end{array}$} & \multicolumn{4}{|c|}{$\begin{array}{l}\text { Bulk density } \\
\qquad\left(\mathrm{g} \mathrm{cm}^{-3}\right)\end{array}$} & \multicolumn{4}{|c|}{$\begin{array}{l}\text { Bulk density } \\
\qquad\left(\mathrm{g} \mathrm{cm}^{-3}\right)\end{array}$} \\
\hline & Mean & SD & Min. & Max. & Mean & SD & Min. & Max. \\
\hline $0-2$ & 0.227 & 0.245 & 0.016 & 1.018 & 1.010 & 0.668 & 0.080 & 2.000 \\
\hline $8-10$ & 0.485 & 0.493 & 0.022 & 1.467 & 1.327 & 0.224 & 1.015 & 1.609 \\
\hline $28-30$ & 0.721 & 0.476 & 0.075 & 1.601 & 1.461 & 0.271 & 1.175 & 1.986 \\
\hline $48-50$ & 0.905 & 0.536 & 0.105 & 1.997 & 1.545 & 0.175 & 1.175 & 1.704 \\
\hline $73-75$ & 0.916 & 0.545 & 0.292 & 1.971 & 1.455 & 0.480 & 0.922 & 2.374 \\
\hline $98-100$ & 0.918 & 0.445 & 0.278 & 1.980 & 1.490 & 0.308 & 0.922 & 1.830 \\
\hline
\end{tabular}

Table 3. Volumetric ice contents for all six investigated soil depths and both geomorphic units, the Holocene river terrace and the active floodplain levels, expressed as percentages with the mean values and the respective standard deviations as well as the minima and maxima. Cores were sampled in April and completely frozen, including the seasonally thawed layer.

\begin{tabular}{|c|c|c|c|c|c|c|c|c|}
\hline \multirow{3}{*}{$\begin{array}{l}\text { Soil depth } \\
(\mathrm{cm})\end{array}$} & \multicolumn{4}{|c|}{ Holocene River Terrace } & \multicolumn{4}{|c|}{ Active Floodplain Levels } \\
\hline & \multicolumn{4}{|c|}{$\begin{array}{l}\text { Volumetric ice content } \\
\qquad(\%)\end{array}$} & \multicolumn{4}{|c|}{$\begin{array}{l}\text { Volumetric ice content } \\
\qquad(\%)\end{array}$} \\
\hline & Mean & SD & Min. & Max. & Mean & SD & Min. & Max. \\
\hline $0-2$ & 61.0 & 20.7 & 9.0 & 89.9 & 44.1 & 25.5 & 15.8 & 89.9 \\
\hline $8-10$ & 70.0 & 18.6 & 43.4 & 100.0 & 46.9 & 24.6 & 17.3 & 88.4 \\
\hline $28-30$ & 69.7 & 19.8 & 41.2 & 93.2 & 30.7 & 22.2 & 8.1 & 57.9 \\
\hline $48-50$ & 67.1 & 15.6 & 43.2 & 87.9 & 26.7 & 17.8 & 6.2 & 50.2 \\
\hline $73-75$ & 67.3 & 20.9 & 28.2 & 97.4 & 30.0 & 21.6 & 8.6 & 75.3 \\
\hline $98-100$ & 66.7 & 16.9 & 33.6 & 95.3 & 33.8 & 24.7 & 8.6 & 79.7 \\
\hline
\end{tabular}

\section{Results}

\subsection{Analytical results}

The mean $\rho_{\mathrm{d}}$ within the floodplain soils varied among the different six investigated soil layers from $1.0 \mathrm{~g} \mathrm{~cm}^{-3} \pm 0.7 \mathrm{~g} \mathrm{~cm}^{-3}$ to $1.5 \mathrm{~g} \mathrm{~cm}^{-3} \pm 0.3 \mathrm{~g} \mathrm{~cm}^{-3}$ whereas the mean $\rho_{\mathrm{d}}$ of the soils sampled on the higher elevated river terrace varied between $0.2 \mathrm{~g} \mathrm{~cm}^{-3} \pm 0.3 \mathrm{~g} \mathrm{~cm}^{-3}$ and $0.9 \mathrm{~g} \mathrm{~cm}^{-3} \pm 0.5 \mathrm{~g} \mathrm{~cm}^{-3}$ (Table 2). The results generally showed a high scatter ranging from $0.08 \mathrm{~g} \mathrm{~cm}^{-3}$ to $2.37 \mathrm{~g} \mathrm{~cm}^{-3}$ at the floodplains and $0.02 \mathrm{~g} \mathrm{~cm}^{-3}$ to $2.0 \mathrm{~g} \mathrm{~cm}^{-3}$ at the river terrace, respectively. Within the soil profiles there was a clear increase of the mean $\rho_{\mathrm{d}}$ with depth to a point where the $\rho_{\mathrm{d}}$ reached a relatively stable value with depth. For the soils of the river terrace, this point was around $30 \mathrm{~cm}$ below the soil surface for an $\rho_{\mathrm{d}}$ of about $0.9 \mathrm{~g} \mathrm{~cm}^{-3}$. For the active floodplain levels, it was around $10 \mathrm{~cm}$ below the soil surface for an $\rho_{\mathrm{d}}$ of $1.5 \mathrm{~g} \mathrm{~cm}^{-3}$ (Table 2).

The ice contents were higher in soils of the Holocene river terrace than in soils of the active floodplain levels. The soils of the river terrace had mean volumetric ice contents of more than $65 \%$, the soils of the floodplains mean contents of around $35 \%$, respectively (Table 3). The results of the volumetric ice content determination showed in soils of the Holocene river terrace a smooth distribution with depth and values of $61 \% \pm 21 \%$ to $70 \% \pm 19 \%$. Within the soils of the floodplain the values of the ice contents scattered between $27 \% \pm 18 \%$ and $47 \% \pm 25 \%$ (Table 3 ).

The gravimetric contents of organic carbon $c_{\mathrm{OC}}$ showed a high scatter ranging from $0.17 \%$ to $42.46 \%$ in the soils of the Holocene river terrace and ranging from $0.13 \%$ to $27.71 \%$ in the soils of the active floodplain levels (Fig. 4a, b). The highest mean $c_{\mathrm{OC}}$ were measured in the soil surface layers $(0-2 \mathrm{~cm})$ (river terrace: $21.85 \% \pm 10.86 \%$, active floodplains: $5.89 \% \pm 9.88 \%$ ), followed by the soil layers in the depth from $8-10 \mathrm{~cm}$ (river terrace: $12.77 \% \pm 9.60 \%$, active floodplains: $1.65 \% \pm 1.49 \%)$. The soils of the river terrace had significantly higher $c_{\mathrm{OC}}$ than the soils of the active floodplains (One-way ANOVA: $p=0.002-0.047$ ).

The gravimetric contents of total $\mathrm{N} c_{\mathrm{N}}$ were significantly higher (One-way ANOVA: $p=0.001-0.049$ ) in the soils of the river terrace than in the soils of the active floodplains (Fig. 5). There was a distinct decrease of the contents 
Table 4. Results of the $\mathrm{C} / \mathrm{N}$ ratio determination for all six investigated soil depths and both geomorphic units, the Holocene river terrace and the active floodplain levels, with the mean values and the respective standard deviations as well as the minima and maxima.

\begin{tabular}{lrrrr|rrrr}
\hline & \multicolumn{3}{c|}{ Holocene River Terrace } & \multicolumn{4}{c}{ Active Floodplain Levels } \\
\hline $\begin{array}{l}\text { Soil depth } \\
\text { (cm) }\end{array}$ & \multicolumn{4}{c}{ C/N ratio } & \multicolumn{4}{c}{ C/N ratio } \\
\hline $0-2$ & 41.39 & 13.64 & 16.19 & 67.08 & 20.93 & 10.89 & 12.90 & 41.54 \\
$8-10$ & 32.88 & 13.21 & 15.00 & 69.65 & 17.18 & 5.134 & 12.34 & 26.39 \\
$28-30$ & 28.49 & 11.73 & 12.32 & 51.05 & 15.50 & 3.438 & 12.52 & 22.54 \\
$48-50$ & 24.19 & 12.22 & 8.60 & 60.25 & 14.81 & 2.183 & 12.75 & 18.49 \\
$73-75$ & 23.75 & 8.53 & 11.04 & 39.55 & 13.68 & 2.50 & 10.52 & 17.11 \\
$98-100$ & 20.73 & 7.75 & 10.24 & 40.09 & 13.32 & 1.86 & 10.79 & 15.99 \\
\hline
\end{tabular}

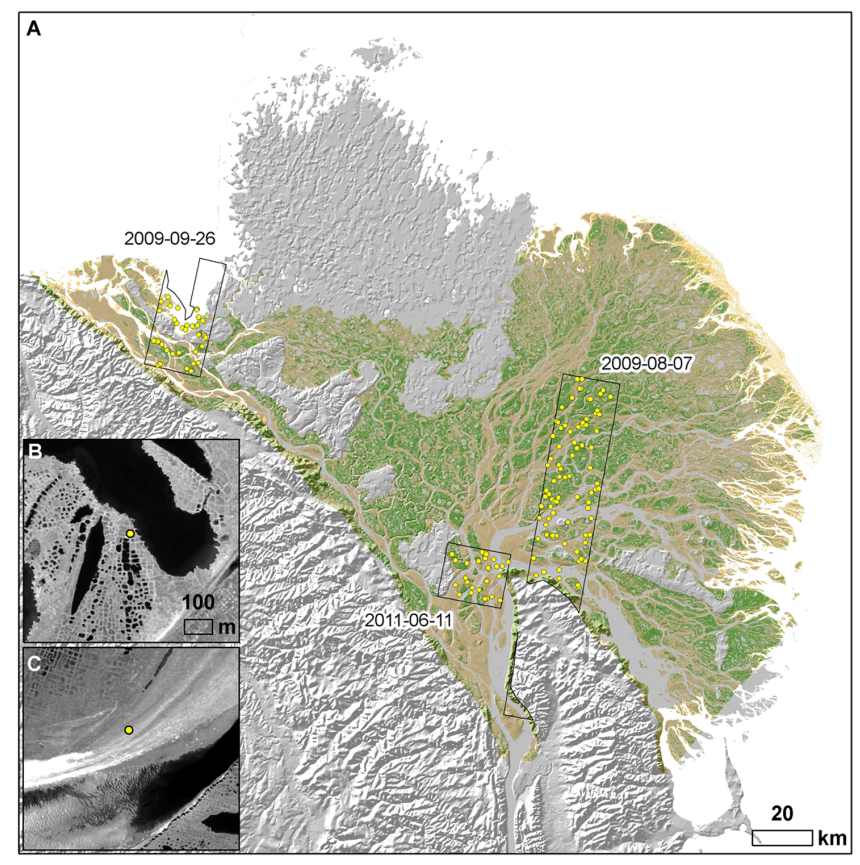

Fig. 3. (A) Delta classification overview showing areas covered with very high resolution WorldView-1 data (־ DigitalGlobe) (black frames, including acquisition date) used for ground truth of the classification (150 yellow dots). (B) Example of ground truth point on Holocene terrace. (C) Example of ground truth point on active floodplain.

with increasing depth of the soil profile within both morphological units: from $0.51 \% \pm 0.20 \%$ in the surface layers to $0.21 \% \pm 0.15 \%$ at a depth of $98-100 \mathrm{~cm}$ in the soils of the river terrace and from $0.19 \% \pm 0.23 \%$ in the surface layers to $0.05 \% \pm 0.003 \%$ at a depth of $98-100 \mathrm{~cm}$ in the soils of the active floodplain levels. The $c_{\mathrm{N}}$ ranged between $0.01 \%$ and $0.90 \%$ in the soils of the river terrace and between $0.01 \%$ and $0.67 \%$ in the soils of the active floodplains, respectively.

The $\mathrm{C} / \mathrm{N}$ ratios ranged between 9 and 70 and were distinctly different in the soils of the river terrace and the soils
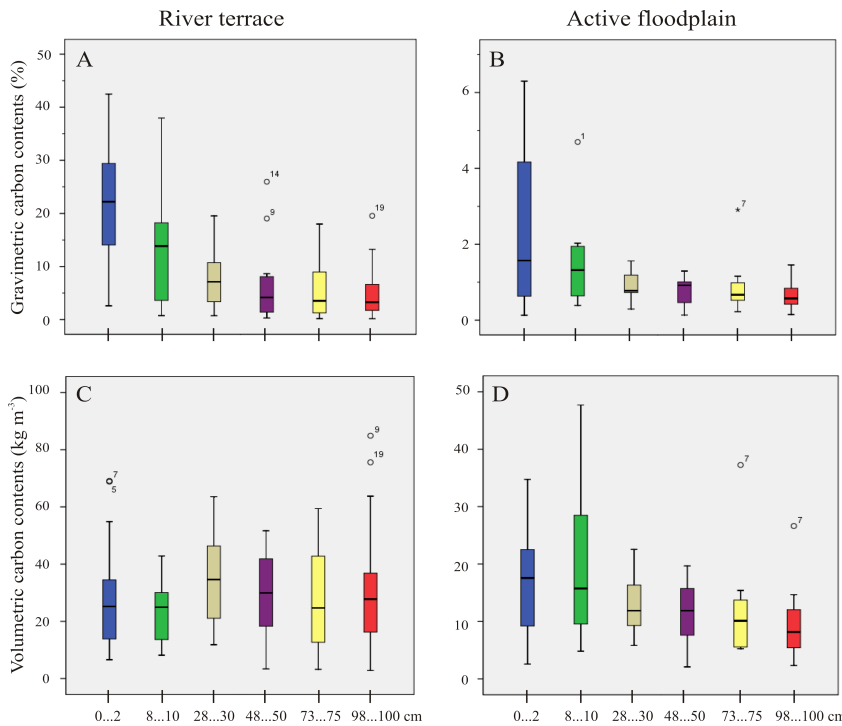

Fig. 4. (A), (B) Gravimetric contents of organic carbon (\%) in the investigated soils layers $(i=1-6)$ of the Holocene river terrace (A) and the active floodplain levels (B). In (B) and the depth of 0-2 $(i=1)$ an extreme value of $27 \%$ was removed prior plotting. (C), (D) Volumetric contents of organic carbon for all six investigated horizons $(i=1-6)\left(\mathrm{kg} \mathrm{m}^{-3}\right)$ of the Holocene river terrace (C) and the active floodplain levels (D). Note different scale for $y$ axis on the graphs. Central black line: median, lower/upper box end: lower/upper quartile, lower/upper horizontal bar: minimum, maximum. Outliers (values between 1.5 and 3 times the interquartile range from a quartile) are marked by circles, extreme values (values more than 3 times the interquartile range) by asterisks.

of the active floodplains and additionally varied with depth (Table 4). The mean $\mathrm{C} / \mathrm{N}$ ratios in the uppermost layers were $41 \pm 14$ at the river terrace and $21 \pm 11$ at the floodplains, respectively. In the deepest investigated soil layers $(98-100 \mathrm{~cm})$, the $\mathrm{C} / \mathrm{N}$ ratios were $21 \pm 8$ at the river terrace and $13 \pm 2$ at the floodplains, respectively. 


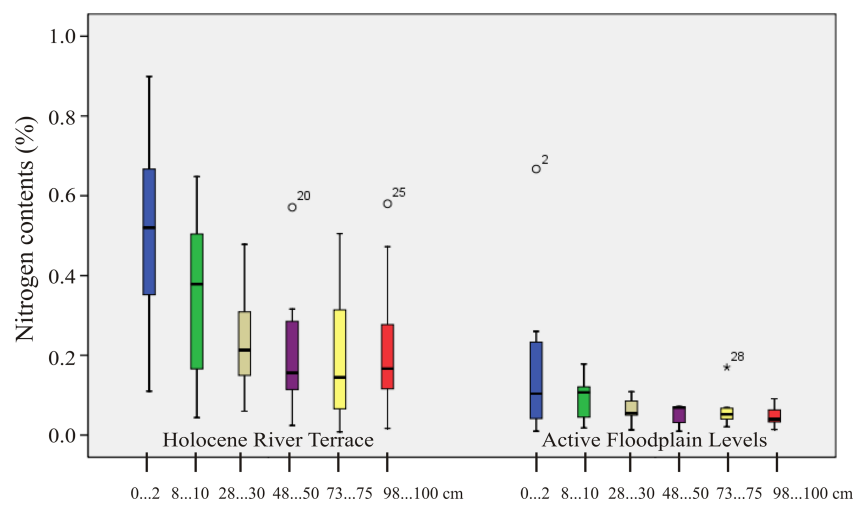

Fig. 5. Gravimetric contents of nitrogen (\%) in the investigated soils layers $(i=1-6)$ and geomorphic units. Central black line: median, lower/upper box end: lower/upper quartile, lower/upper horizontal bar: minimum, maximum. Outliers (values between 1.5 and 3 times the interquartile range from a quartile) are marked by circles, extreme values (values more than 3 times the interquartile range) by asterisks.

\subsection{Soil organic carbon stocks}

The overall mean SOC stock estimated for a reference depth of $1 \mathrm{~m} S_{\mathrm{OC}}(100 \mathrm{~cm})$ using all selected cores $(N=29)$ was $25.7 \mathrm{~kg} \mathrm{~m}^{-2} \pm 12.0 \mathrm{~kg} \mathrm{~m}^{-2}$, with a median of $24.9 \mathrm{~kg} \mathrm{~m}^{-2}$. The estimated $S_{\mathrm{OC}}(100 \mathrm{~cm})$ had a minimum of $6.5 \mathrm{~kg} \mathrm{~m}^{-2}$ and a maximum of $48.6 \mathrm{~kg} \mathrm{~m}^{-2}$.

The SOC stock within the seasonally thawed active layer $(0-50 \mathrm{~cm}) S_{\mathrm{OC}}(50 \mathrm{~cm})$ reached $13.0 \mathrm{~kg} \mathrm{~m}^{-2} \pm 5.3 \mathrm{~kg} \mathrm{~m}^{-2}$. The perennially frozen soil layers $(50-100 \mathrm{~cm})$ store $49 \%$ of the entire estimated $S_{\mathrm{OC}}(100 \mathrm{~cm})$. The summed total stocks for the reference depths of $0-30 \mathrm{~cm}, 0-75 \mathrm{~cm}$ were: $7.7 \mathrm{~kg} \mathrm{~m}^{-2} \pm 3.2 \mathrm{~kg} \mathrm{~m}^{-2}$ and $19.2 \mathrm{~kg} \mathrm{~m}^{-2} \pm 8.5 \mathrm{~kg} \mathrm{~m}^{-2}$, respectively.

\subsubsection{Holocene river terrace and the active floodplains}

The $S_{\mathrm{OC}}(100 \mathrm{~cm})$ for the soils across the investigated island showed a broad range of $42.0 \mathrm{~kg} \mathrm{~m}^{-2}$, indicating a high heterogeneity among the sampled cores. To get a more differentiated picture of the SOC stocks of the two geomorphic units, we separated the samples of the Holocene river terrace $(N=22)$ and the floodplain $(N=7)$, respectively. We found pronounced differences between the soils in these two units. Generally, distinctly higher $S_{\mathrm{OC}}\left(h_{\mathrm{r}}\right)$ were found in the soils of the Holocene river terrace (Figs. 6, 4c, d). The mean $S_{\mathrm{OC}}(100 \mathrm{~cm})$ in soils of the river terrace was estimated at $29.5 \mathrm{~kg} \mathrm{~m}^{-2} \pm 10.5 \mathrm{~kg} \mathrm{~m}^{-2}$ with a median of $27.0 \mathrm{~kg} \mathrm{~m}^{-2}$ (minimum $12.7 \mathrm{~kg} \mathrm{~m}^{-2}$, maximum $48.5 \mathrm{~kg} \mathrm{~m}^{-2}$ ). The $S_{\mathrm{OC}}$ $(100 \mathrm{~cm})$ in soils of the active floodplains were lower with a mean of $13.6 \mathrm{~kg} \mathrm{~m}^{-2} \pm 7.4 \mathrm{~kg} \mathrm{~m}^{-2}$ and a median of $11.6 \mathrm{~kg} \mathrm{~m}^{-2}$ (minimum $6.5 \mathrm{~kg} \mathrm{~m}^{-2}$, maximum $26.6 \mathrm{~kg} \mathrm{~m}^{-2}$ ).
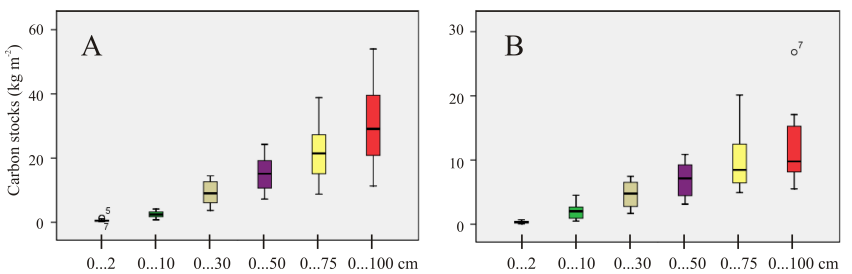

Fig. 6. The cumulative carbon stock for all six investigated depths of the Holocene river terrace (A) and of the active floodplains (B) on Samoylov Island $\left(\mathrm{kg} \mathrm{m}^{-2}\right)$. Note different scale for $y$-axis on the graphs.

\subsubsection{Polygon centres, polygon rims, and soil units}

To account for pronounced small-scale spatial soil variability within the polygonal tundra of the Holocene river terrace, we analysed and compared the characteristics of cores from the polygon rims $(N=6)$ and from the polygon centres $(N=$ 16 ). Additionally, separate core analyses were done on the soil subgroup level.

The estimated mean SOC stock within the surface layers $S_{\mathrm{OC}}(2 \mathrm{~cm})$ was substantially higher in the polygon rims $\left(0.9 \mathrm{~kg} \mathrm{~m}^{-2} \pm 0.5 \mathrm{~kg} \mathrm{~m}^{-2}\right)$ than for the corresponding layers in the polygon centres $\left(0.5 \mathrm{~kg} \mathrm{~m}^{-2} \pm 0.3 \mathrm{~kg} \mathrm{~m}^{-2}\right)$. Including the soil layers down to $10 \mathrm{~cm}$ depth, this difference decreased $\left(S_{\mathrm{OC}}(10 \mathrm{~cm})\right.$ was $3.2 \mathrm{~kg} \mathrm{~m}^{-2} \pm 1.5 \mathrm{~kg} \mathrm{~m}^{-2}$ for the rims and $2.5 \mathrm{~kg} \mathrm{~m}^{-2} \pm 0.9 \mathrm{~kg} \mathrm{~m}^{-2}$ for the centres). The estimated mean SOC stock within $30 \mathrm{~cm}$ depth $S_{\mathrm{OC}}(30 \mathrm{~cm})$ was slightly higher in the centres $\left(8.8 \mathrm{~kg} \mathrm{~m}^{-2} \pm 2.8 \mathrm{~kg} \mathrm{~m}^{-2}\right)$ than at the rims $\left(7.5 \mathrm{~kg} \mathrm{~m}^{-2} \pm 3.1 \mathrm{~kg} \mathrm{~m}^{-2}\right)$. The mean SOC stock over $1 \mathrm{~m}$ deep soil profiles $S_{\mathrm{OC}}(100 \mathrm{~cm})$ was $33.3 \mathrm{~kg} \mathrm{~m}^{-2} \pm 9.7 \mathrm{~kg} \mathrm{~m}^{-2}$ in the centres with a median of $34.5 \mathrm{~kg} \mathrm{~m}^{-2}$, whereas at the polygonal rims the mean $S_{\mathrm{OC}}$ $(100 \mathrm{~cm})$ was $19.4 \mathrm{~kg} \mathrm{~m}^{-2} \pm 3.7 \mathrm{~kg} \mathrm{~m}^{-2}$ with a median of $19.5 \mathrm{~kg} \mathrm{~m}^{-2}$.

The results of the analyses on soil subgroup level indicated a large variability among the eight known soil subgroups of Samoylov Island (Fig. 7). The $S_{\mathrm{OC}}(100 \mathrm{~cm})$ estimates based on the one sampled core were $31.1 \mathrm{~kg} \mathrm{~m}^{-2}$ for the Typic Aquorthel (silty) and $45.3 \mathrm{~kg} \mathrm{~m}^{-2}$ for the Typic Aquiturbel/Typic Aquorthel soil complex, respectively. The results of the mean $S_{\mathrm{OC}}(100 \mathrm{~cm})$ estimations for the other soil units of Samoylov Island with a higher number of sampled cores showed a high scatter (Fig. 7). Minima ranged from $6.5 \mathrm{~kg} \mathrm{~m}^{-2}$ to $19.5 \mathrm{~kg} \mathrm{~m}^{-2}$, maxima ranged from $20.4 \mathrm{~kg} \mathrm{~m}^{-2}$ to $48.5 \mathrm{~kg} \mathrm{~m}^{-2}$. The mean carbon stocks of the different soils varied strongly within the soil units as well as across the depth profiles (Fig. 8).

\subsection{Nitrogen stocks}

The $S_{\mathrm{N}}(100 \mathrm{~cm})$ of the investigation area varied between $0.41 \mathrm{~kg} \mathrm{~m}^{-2}$ and $1.94 \mathrm{~kg} \mathrm{~m}^{-2}$. The mean $\mathrm{N}$ stock amounted to $1.10 \mathrm{~kg} \mathrm{~m}^{-2} \pm 0.39 \mathrm{~kg} \mathrm{~m}^{-2}$ (Table 5). 


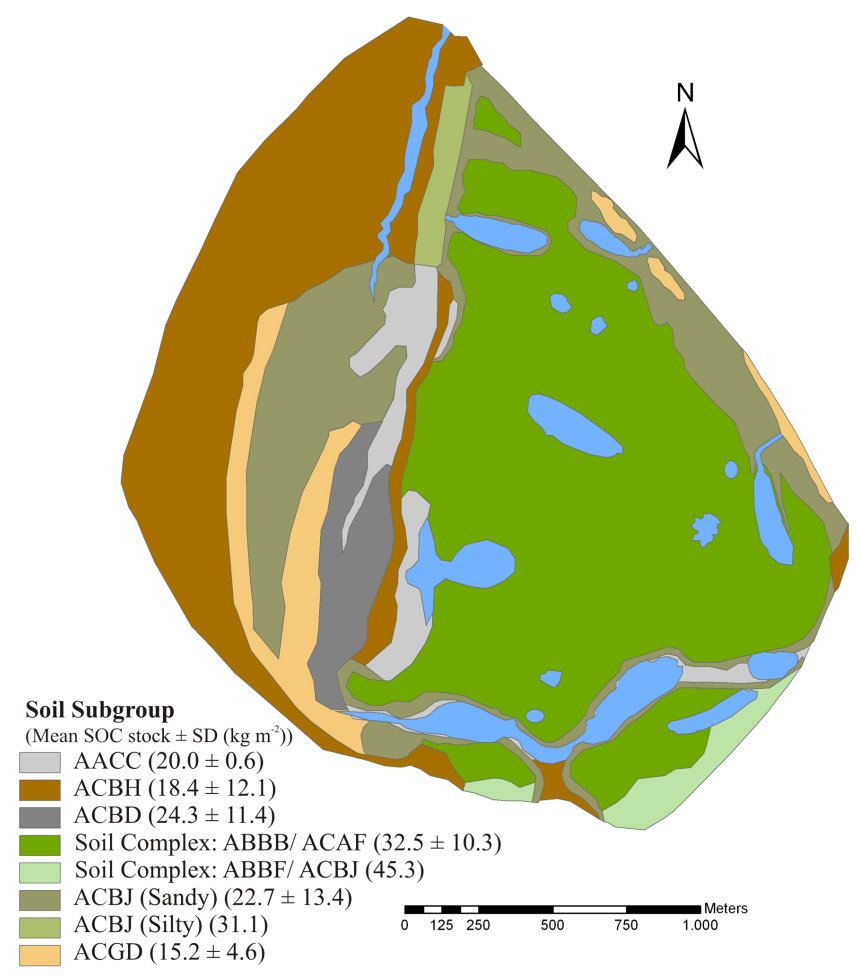

Fig. 7. A soil map of Samoylov Island as a result of long-term soil research within this area. Generated from data by Pfeiffer et al. (2000) and Pfeiffer et al. (2002) (compare Sanders et al., 2010). Soil classification according to the US Soil Taxonomy (Soil Survey Staff, 2010). Mean soil organic carbon stocks with their standard deviations for the soil units down to $100 \mathrm{~cm}$ depth are provided in parentheses after each soil subgroup. (ACRONYM - soil subgroup (number of soil cores)): AACC - Fluvaquentic Fibristel (2), ACBH - Psammentic Aquorthel (5), ACBD - Ruptic-Histic Aquorthel (3), Soil Complex: ABBB/ ACAF - Glacic Aquiturbel/ Typic Historthel (10), Soil Complex: ABBF/ ACBJ - Typic Aquiturbel/ Typic Aquorthel (1), ACBJ - Typic Aquorthel silty (5); sandy (1), ACGD - Typic Psammorthel (3).

Regarding the two different investigated geomorphic units, the Holocene river terrace and the active floodplain levels, the mean $\mathrm{N}$ stocks were $1.18 \mathrm{~kg} \mathrm{~m}^{-2} \pm 0.36 \mathrm{~kg} \mathrm{~m}^{-2}$ and $0.88 \mathrm{~kg} \mathrm{~m}^{-2} \pm 0.40 \mathrm{~kg} \mathrm{~m}^{-2}$, respectively. The distinctly higher total $\mathrm{N}$ stock of the Holocene river terrace had a different vertical distribution. While the active floodplain stored about $53 \%$ of the entire estimated $\mathrm{N}$ stock within the seasonally thawed active layer (depth $0-50 \mathrm{~cm}$ ), only $48 \%$ of the $\mathrm{N}$ stock of the river terrace was determined in the seasonally thawed active layer (Table 5). The polygon centres had higher $S_{\mathrm{N}}(100 \mathrm{~cm})\left(1.26 \mathrm{~kg} \mathrm{~m}^{-2} \pm 0.35 \mathrm{~kg} \mathrm{~m}^{-2}\right)$ than the polygon rims $\left(0.96 \mathrm{~kg} \mathrm{~m}^{-2} \pm 0.31 \mathrm{~kg} \mathrm{~m}^{-2}\right)$. The rim soils stored about $57 \%$ of their $S_{\mathrm{N}}(100 \mathrm{~cm})$ within the seasonally thawed active layer, whereas only $45 \%$ were stored in this active layer at the polygon centre soils (Table 5).
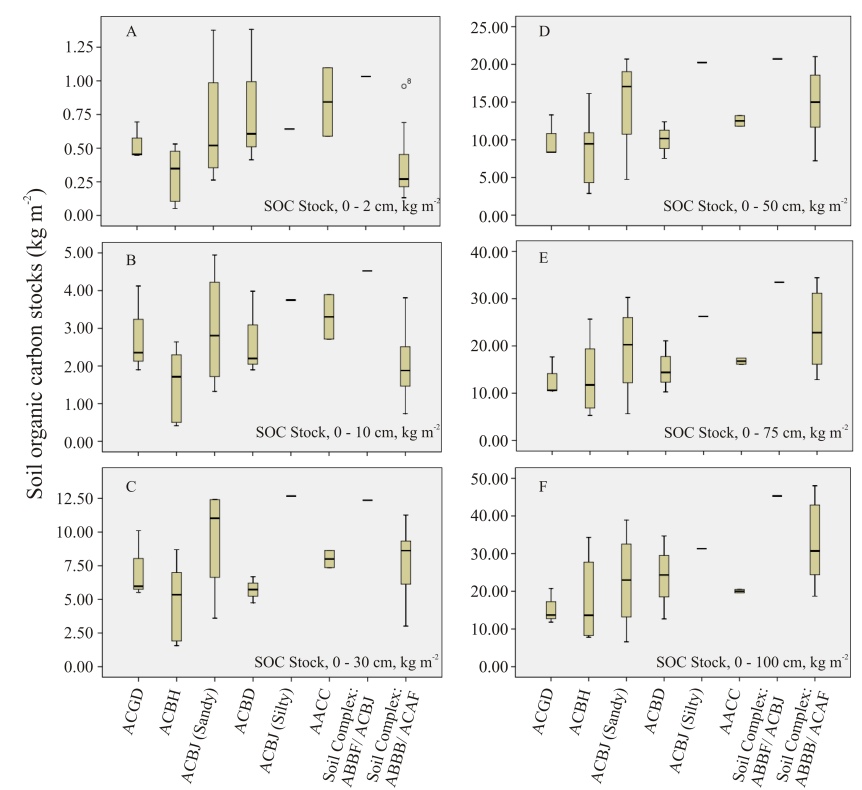

Fig. 8. Soil organic carbon stocks $\left(\mathrm{kg} \mathrm{m}^{-2}\right)$ of the soil subgroups identified on Samoylov Island according to the US Soil Taxonomy (Soil Survey Staff, 2010) for different reference depths $h_{\mathrm{r}}$. (A) $h_{\mathrm{r}}=2 \mathrm{~cm} ;$ (B) $h_{\mathrm{r}}=10 \mathrm{~cm}$; (C) $h_{\mathrm{r}}=30 \mathrm{~cm}$;(D) $h_{\mathrm{r}}=50 \mathrm{~cm}$; (E) $h_{\mathrm{r}}=75 \mathrm{~cm}$; (F) $h_{\mathrm{r}}=100 \mathrm{~cm}$. Note different scale for y-axis on all graphs. For acronyms along x-axis see Fig. 7.

The $S_{\mathrm{N}}(100 \mathrm{~cm})$ for the soil subgroup-related analyses showed mean values between $0.85 \mathrm{~kg} \mathrm{~m}^{-2} \pm 0.31 \mathrm{~kg} \mathrm{~m}^{-2}$ and $1.94 \mathrm{~kg} \mathrm{~m}^{-2}$ for the specific soil subgroups. High $S_{\mathrm{N}}$ $(100 \mathrm{~cm})$ was found in the two soil complexes of Aquiturbels and Historthels that dominate Samoylov Island (Table 6). Regarding the vertical distribution of the $\mathrm{N}$ contents, high differences emerged among the various soil subgroups. On average, $50 \%$ of the $S_{\mathrm{N}}(100 \mathrm{~cm})$ was stored within the upper $50 \mathrm{~cm}$ of soil indicating a homogenous distribution over soil depth. In the soil complex of Glacic Aquiturbels and Typic Historthels, only $42 \%$ was stored within this layer, whereas $63 \%$ of the $S_{\mathrm{N}}(100 \mathrm{~cm})$ was found in the upper $50 \mathrm{~cm}$ of the Typic Aquorthel (silty) (Table 6).

\subsection{Land surface classification and upscaling}

Based on the Landsat-7 ETM+ satellite image mosaic (Fig. 9a), the results of our supervised classification confirmed previously reported ratios of the water- and landcovered areas in the Lena River Delta (Fig. 9b) of approximately $31 \%$ and $69 \%$, respectively (Schneider et al., 2009). The area covered by water bodies $>3600 \mathrm{~m}^{2}$ amounted to around $10000 \mathrm{~km}^{2}$. Furthermore, the results indicated that the geomorphic unit dominating the Lena River Delta are the active floodplain levels occupying about $8830 \mathrm{~km}^{2}$ (Fig. 9c). This area represents approximately $40 \%$ of the soil-covered area of the Lena River Delta. The investigated Holocene river terrace (1st terrace) (Fig. 9c) occupies $4760 \mathrm{~km}^{2}$ which 
Table 5. The nitrogen stocks. The results are expressed in $\mathrm{kg} \mathrm{m}^{-2}$ with the mean values and the respective standard deviations as well as the minima and maxima.

\begin{tabular}{|c|c|c|c|c|c|c|c|c|c|c|c|c|}
\hline & \multicolumn{4}{|c|}{ Entire investigation area } & \multicolumn{4}{|c|}{ Holocene river terrace } & \multicolumn{4}{|c|}{ Active floodplain levels } \\
\hline \multirow[t]{2}{*}{$\begin{array}{l}\text { Soil depth } \\
(\mathrm{cm})\end{array}$} & \multicolumn{4}{|c|}{$\begin{array}{l}\text { Nitrogen stock } \\
\qquad\left(\mathrm{kg} \mathrm{m}^{-2}\right)\end{array}$} & \multicolumn{4}{|c|}{$\begin{array}{l}\text { Nitrogen stock } \\
\quad\left(\mathrm{kg} \mathrm{m}^{-2}\right)\end{array}$} & \multicolumn{4}{|c|}{$\begin{array}{l}\text { Nitrogen stock } \\
\quad\left(\mathrm{kg} \mathrm{m}^{-2}\right)\end{array}$} \\
\hline & Mean & SD & Min. & Max. & Mean & SD & Min. & Max. & Mean & SD & Min. & Max. \\
\hline $0-2$ & 0.02 & 0.01 & 0.00 & 0.05 & 0.02 & 0.01 & 0.00 & 0.05 & 0.02 & 0.01 & 0.00 & 0.03 \\
\hline $0-10$ & 0.09 & 0.05 & 0.01 & 0.23 & 0.09 & 0.05 & 0.01 & 0.23 & 0.10 & 0.05 & 0.02 & 0.15 \\
\hline $0-30$ & 0.31 & 0.15 & 0.06 & 0.76 & 0.31 & 0.16 & 0.06 & 0.76 & 0.30 & 0.15 & 0.08 & 0.49 \\
\hline $0-50$ & 0.54 & 0.23 & 0.15 & 1.23 & 0.57 & 0.23 & 0.16 & 1.23 & 0.47 & 0.21 & 0.15 & 0.74 \\
\hline $0-75$ & 0.81 & 0.30 & 0.24 & 1.62 & 0.86 & 0.30 & 0.24 & 1.62 & 0.68 & 0.29 & 0.32 & 1.17 \\
\hline \multirow[t]{10}{*}{$0-100$} & 1.10 & 0.39 & 0.41 & 1.94 & 1.18 & 0.36 & 0.41 & 1.94 & 0.88 & 0.40 & 0.49 & 1.65 \\
\hline & & & \multicolumn{4}{|c|}{ Polygon centres } & \multicolumn{4}{|c|}{ Polygon rims } & & \\
\hline & \multirow{2}{*}{\multicolumn{2}{|c|}{$\begin{array}{l}\text { Soil depth } \\
(\mathrm{cm})\end{array}$}} & \multicolumn{4}{|c|}{$\begin{array}{l}\text { Nitrogen stock } \\
\quad\left(\mathrm{kg} \mathrm{m}^{-2}\right)\end{array}$} & \multicolumn{4}{|c|}{$\begin{array}{c}\text { Nitrogen stock } \\
\left(\mathrm{kg} \mathrm{m}^{-2}\right)\end{array}$} & & \\
\hline & & & Mean & SD & Min. & Max. & Mean & SD & Min. & Max. & & \\
\hline & $0-2$ & & 0.02 & 0.01 & 0.00 & 0.05 & 0.02 & 0.01 & 0.00 & 0.03 & & \\
\hline & $0-1$ & & 0.08 & 0.06 & 0.03 & 0.23 & 0.09 & 0.04 & 0.01 & 0.13 & & \\
\hline & $0-3$ & & 0.30 & 0.16 & 0.10 & 0.76 & 0.33 & 0.17 & 0.06 & 0.57 & & \\
\hline & $0-5$ & & 0.57 & 0.24 & 0.24 & 1.23 & 0.55 & 0.24 & 0.16 & 0.87 & & \\
\hline & $0-7$ & & 0.90 & 0.30 & 0.45 & 1.62 & 0.74 & 0.28 & 0.24 & 0.99 & & \\
\hline & $0-1$ & & 1.26 & 0.35 & 0.78 & 1.94 & 0.96 & 0.31 & 0.41 & 1.26 & & \\
\hline
\end{tabular}

represents around $22 \%$ of the soil-covered area of the Lena River Delta. According to Morgenstern et al. (2008) the other geomorphic parts of the Lena River Delta account to $6099 \mathrm{~km}^{2}$ (2nd terrace) and $1712 \mathrm{~km}^{2}$ (3rd terrace). The overall accuracy of our classification aiming at separating the Holocene river terrace and the active floodplain was $77 \%$, with a producer accuracy of $78 \%$ and a user accuracy of $78 \%$ (Table 7). This accuracy is on the same level as a previous Landsat-based land cover classification in the Lena River Delta using the same image mosaic that focused on classes useful for methane emission assessment (Schneider et al., 2009; overall accuracy of $78 \%$ ). In our classification, part of the observed misclassification between water and non-water classes may be related to the different acquisition dates of the imagery that may result in somewhat different water levels and hence exposure or inundation of surfaces especially for the active floodplain.

After correcting for the spatial coverage of small ponds in the polygonal tundra of the Holocene river terrace, the soil covered land area of the river terrace, which we used for later calculations and upscaling, amounted to $4090 \mathrm{~km}^{2}$.

The results of the upscaling (Fig. 9d) reflect the nearlinear increase of SOC stocks with increasing reference soil depths that was found in the analysed soil cores from Samoylov Island. The surface soil layers ranging from 0 $2 \mathrm{~cm}$ store a total SOC mass of $2.4 \mathrm{Tg} \pm 1.5 \mathrm{Tg}$ on the Holocene river terrace and $3.0 \mathrm{Tg} \pm 2.0 \mathrm{Tg}$ on the active floodplain, respectively. We estimated for the reference depth of $50 \mathrm{~cm}$ a $\mathrm{SOC}$ pool of $59.9 \mathrm{Tg} \pm 18.5 \mathrm{Tg}$ for the river terrace and $67.2 \mathrm{Tg} \pm 34.0 \mathrm{Tg}$ for the floodplains (Table 8). This depth is approximately the average depth of the seasonally thawed active layer in the summer. The total pools of the SOC stored within a depth of $100 \mathrm{~cm}$ were estimated at $120.7 \mathrm{Tg} \pm 43.0 \mathrm{Tg}$ on the Holocene river terrace and at $119.8 \mathrm{Tg} \pm 65.6 \mathrm{Tg}$ on the active floodplains of the Lena River Delta. Roughly $47 \%$ of the SOC mass stored within the top $100 \mathrm{~cm}$ of soils in the investigation area, specifically about $61 \mathrm{Tg}$ at the young river terrace and $53 \mathrm{Tg}$ at the floodplains, are located within the currently perennially frozen layers deeper than $50 \mathrm{~cm}$.

The $\mathrm{N}$ stored within the top $100 \mathrm{~cm}$ of soils was estimated at $4.8 \mathrm{Tg} \pm 1.5 \mathrm{Tg}$ for the Holocene river terrace and at $7.7 \mathrm{Tg} \pm 3.6 \mathrm{Tg}$ on the active floodplains of the Lena River Delta. About $49 \%$ of this N pool within the top $100 \mathrm{~cm}$ of soils was found within the currently perennially frozen layers. This proportion was $52 \%$ on the Holocene river terrace, and $47 \%$ on the active floodplains (Table 9).

\section{Discussion}

\subsection{Soil organic carbon pools on the Holocene river terrace and the active floodplains}

In this study, we do not consider woody debris in our estimates due to its spatially very inhomogeneous distribution and basically absent field data. However, there is certainly 
Table 6. The nitrogen stocks of the soil subgroups of Samoylov Island. The results are expressed in $\mathrm{kg} \mathrm{m}^{-2}$ with the mean values and the respective standard deviations as well as the minima and maxima.

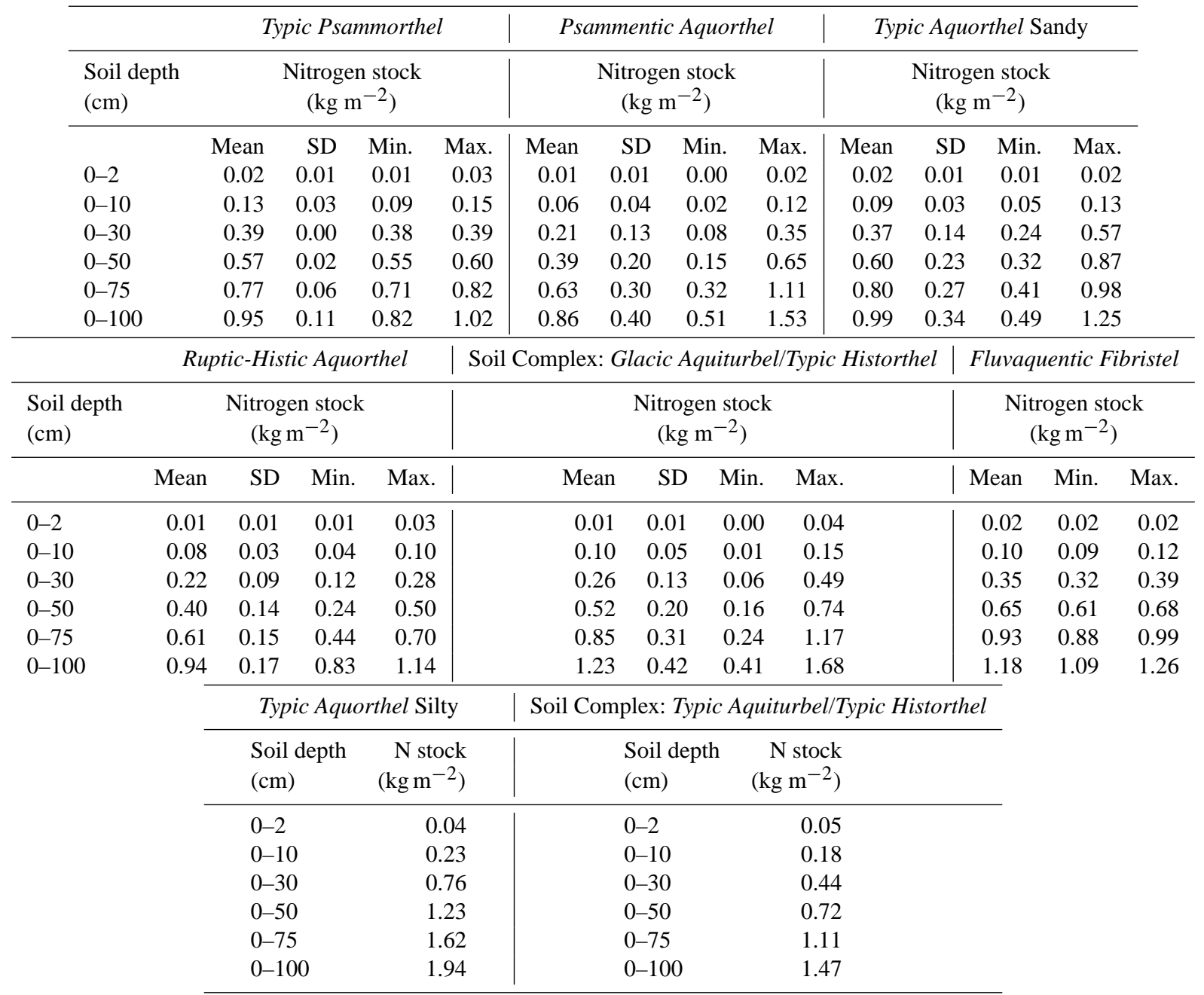

Table 7. Accuracy assessment of Landsat-based geomorphic land unit classification for the Holocene terrace, the active floodplain and water, using high-resolution WorldView-1 data.

\begin{tabular}{lrrrr|rr}
\hline WorldView-1 & $\begin{array}{r}\text { Active } \\
\text { floodplains }\end{array}$ & $\begin{array}{r}\text { Holocene } \\
\text { terrace }\end{array}$ & Water & Other* & Total & $\begin{array}{r}\text { User's } \\
\text { accuracy }\end{array}$ \\
\hline Active floodplains & 42 & 8 & 5 & 0 & 55 & $76.4 \%$ \\
Holocene terrace & 10 & 33 & 2 & 0 & 45 & $73.3 \%$ \\
Water & 6 & 1 & 41 & 0 & 48 & $85.4 \%$ \\
Other* & 2 & 0 & 0 & 0 & 2 & 0 \\
Total & 60 & 42 & 48 & 0 & 150 & \\
\hline Producer's accuracy & $70.0 \%$ & $78.6 \%$ & $85.4 \%$ & 0 & & $77.3 \%$ \\
\hline
\end{tabular}

* Other includes coastal beach and a drained lake basin on the 2nd geomorphic delta terrace.

a considerable $\mathrm{C}$ stock in the Holocene delta area that consists entirely of wood trunks buried in soils. Our mean $S_{\mathrm{OC}}$ $(100 \mathrm{~cm})$ estimate for the soils of the Holocene river terrace amounts to $29.5 \mathrm{~kg} \mathrm{~m}^{-2} \pm 10.5 \mathrm{~kg} \mathrm{~m}^{-2}$ and is distinctly higher than some older published estimates of mean organic carbon stocks stored in permafrost-affected tundra soils. Post et al. (1982) estimated the average SOC stock in tundra soils worldwide at $21.8 \mathrm{~kg} \mathrm{~m}^{-2}$. Kolchugina et al. (1995) pro- 

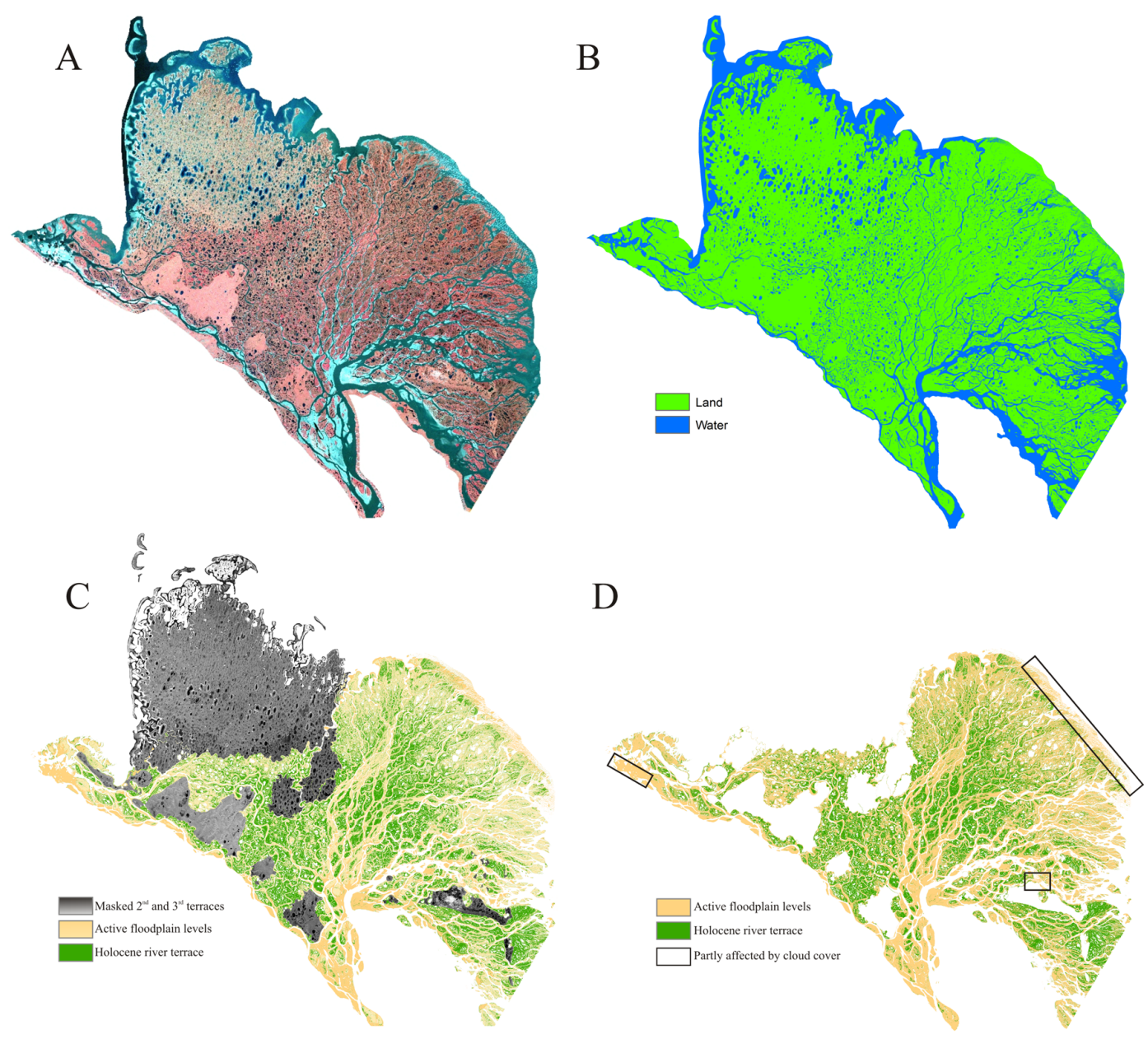

Fig. 9. Landsat-7 ETM+ remote-sensing image mosaic of the Lena River Delta from 27 July 2000 and 26 July 2001 (A), results of land-water classification (B), results of classification into main geomorphic terraces $(\mathbf{C})$, and upscaling of soil organic carbon stocks to Holocene river terrace and active floodplain levels (D).

vided an estimate of $21.4 \mathrm{~kg} \mathrm{~m}^{-2}$ for Russian tundra soils, whereas Matsuura and Yefremov (1995) estimated the SOC stock in Russian permafrost-affected soils to be between $11 \mathrm{~kg} \mathrm{~m}^{-2}$ and $20 \mathrm{~kg} \mathrm{~m}^{-2}$. Chestnyck et al. (1999) estimated the SOC stock in East European Russian tundra soil at $17.8 \mathrm{~kg} \mathrm{~m}^{-2}$. More recent publications, however, provided higher stocks for tundra soils. Gundelwein et al. (2007) estimated the SOC stock in tundra soils of the Taymyr Peninsula at $30.7 \mathrm{~kg} \mathrm{~m}^{-2}$. For the North American Arctic lowlands, Ping et al. (2008) reported SOC stocks of $25.9 \mathrm{~kg} \mathrm{~m}^{-2}$. Tarnocai et al. (2009) estimated the organic carbon stocks in Turbels and Orthels of the circumpolar permafrost at $32.2 \mathrm{~kg} \mathrm{~m}^{-2}$ and $22.6 \mathrm{~kg} \mathrm{~m}^{-2}$, respectively. Hugelius and Kuhry (2009) estimated the stocks in northeastern European Russian tundra soils at $38.7 \mathrm{~kg} \mathrm{~m}^{-2}$. Only Stolbovoi et al. (2006) reported a lower stock estimate of $16.6 \mathrm{~kg} \mathrm{~m}^{-2}$ for Russian tundra soils. Ping et al. (2011) found a stock of $41 \mathrm{~kg} \mathrm{~m}^{-2}$ in river deltas along the Alaska Beaufort Sea coastline. The estimate we provide for the Holocene river terrace $\left(29.5 \mathrm{~kg} \mathrm{~m}^{-2}\right)$ lies in the range of the more recently reported estimates. The estimate for soils of the active floodplains of $13.6 \mathrm{~kg} \mathrm{~m}^{-2} \pm 7.4 \mathrm{~kg} \mathrm{~m}^{-2}$ cannot readily be compared with general estimates for tundra regions. Due to their fluvial origin and ongoing episodic reworking, the soils of the Lena River Delta floodplains consist of stratified middle to fine sands and silts with layers of allochthonous organic matter as well as autochthonous peat (Boike et al., 2012). Parts of the floodplain are densly vegetated. However, generally the regular flooding events enable only sparse vegetation adjacent to the river channel. Though, our estimate is still notably higher than the mean $\mathrm{C}$ stock of sparse tundra $\left(1.4 \mathrm{~kg} \mathrm{~m}^{-2}\right)$ in the database used by Hugelius and Kuhry (2009). Hugelius et al. (2011) reported a SOC stock for the sediments of the Rogovaya River in northeastern European Russia of $11.7 \mathrm{~kg} \mathrm{~m}^{-2}$ which is very close to the estimate we present for the soils of the active floodplain strongly affected by active fluvial sedimentation by the Lena River. 
Table 8. The vertical distributions of the total soil organic carbon mass within the seasonally thawed and perennially frozen soil for the Holocene river terrace (A) and the active floodplain levels (B) in the Lena River Delta. Represented are the estimated mean soil carbon mass $(\mathrm{Tg})$ for all investigated soil horizons (Mass $\mathrm{h}$ ) and the estimated mean soil organic carbon mass (Tg) for different depth increments (Mass $\mathrm{i}_{\mathrm{i}}$ ) with the respective standard deviations.

\begin{tabular}{|c|c|c|c|c|c|}
\hline \multirow[t]{2}{*}{ A } & \multicolumn{5}{|c|}{ Holocene River Terrace area: $4090 \mathrm{~km}^{2}$} \\
\hline & $\begin{array}{r}\text { Soil depth } \\
(\mathrm{cm})\end{array}$ & $\begin{array}{r}\text { Mass }_{h} \\
(\mathrm{Tg})\end{array}$ & $\begin{array}{r}\text { Soil depth } \\
(\mathrm{cm})\end{array}$ & $\begin{array}{r}\text { Mass }_{i} \\
(\mathrm{Tg})\end{array}$ & $\begin{array}{r}\text { SD } \\
(\mathrm{Tg})\end{array}$ \\
\hline & $0-2$ & 2.41 & $0-2$ & 2.41 & 1.50 \\
\hline \multirow[t]{3}{*}{ thawed soil } & $2-10$ & 8.52 & $0-10$ & 10.93 & 4.61 \\
\hline & $10-30$ & 23.63 & $0-30$ & 34.56 & 11.59 \\
\hline & $30-50$ & 25.35 & $0-50$ & 59.91 & 18.50 \\
\hline \multirow[t]{2}{*}{ Permafrost } & $50-75$ & 29.85 & $0-75$ & 89.76 & 30.33 \\
\hline & $75-100$ & 30.90 & $0-100$ & 120.66 & 42.96 \\
\hline \multirow[t]{2}{*}{ B } & \multicolumn{5}{|c|}{ Active Floodplain Levels area: $8830 \mathrm{~km}^{2}$} \\
\hline & $\begin{array}{r}\text { Soil depth } \\
(\mathrm{cm})\end{array}$ & $\begin{array}{r}\text { Mass }_{h} \\
(\mathrm{Tg})\end{array}$ & $\begin{array}{r}\text { Soil depth } \\
(\mathrm{cm})\end{array}$ & $\begin{array}{r}\text { Mass }_{i} \\
(\mathrm{Tg})\end{array}$ & $\begin{array}{r}\text { SD } \\
(\mathrm{Tg})\end{array}$ \\
\hline \multirow{4}{*}{$\begin{array}{l}\text { Seasonally } \\
\text { thawed soil }\end{array}$} & $0-2$ & 2.99 & 0-2 & 2.99 & 1.96 \\
\hline & $2-10$ & 13.58 & $0-10$ & 16.57 & 11.39 \\
\hline & $10-30$ & 29.07 & $0-30$ & 45.64 & 26.76 \\
\hline & $30-50$ & 21.53 & $0-50$ & 67.17 & 33.99 \\
\hline \multirow[t]{2}{*}{ Permafrost } & $50-75$ & 27.17 & $0-75$ & 94.34 & 48.17 \\
\hline & $75-100$ & 25.49 & $0-100$ & 119.83 & 65.63 \\
\hline
\end{tabular}

Table 9. The vertical distributions of the total nitrogen mass within the seasonally thawed and perennially frozen soil for the Holocene river terrace (A) and the active floodplain levels (B) in the Lena River Delta. Represented are the estimated mean total nitrogen mass (Tg) for all investigated soil horizons (Mass ${ }_{h}$ ) and the estimated mean total nitrogen mass (Tg) for different depth increments (Mass ${ }_{i}$ ) with the respective standard deviations.

\begin{tabular}{|c|c|c|c|c|c|}
\hline \multirow[t]{2}{*}{ A } & \multicolumn{5}{|c|}{ Holocene River Terrace area: $4090 \mathrm{~km}^{2}$} \\
\hline & $\begin{array}{r}\text { Soil depth } \\
(\mathrm{cm})\end{array}$ & $\begin{array}{r}\text { Massh } \\
(\mathrm{Tg})\end{array}$ & $\begin{array}{r}\text { Soil depth } \\
(\mathrm{cm})\end{array}$ & $\begin{array}{r}\text { Mass }_{i} \\
(\mathrm{Tg})\end{array}$ & $\begin{array}{r}\text { SD } \\
(\mathrm{Tg})\end{array}$ \\
\hline \multirow{4}{*}{$\begin{array}{l}\text { Seasonally } \\
\text { thawed soil }\end{array}$} & $0-2$ & 0.07 & $0-2$ & 0.07 & 0.05 \\
\hline & $2-10$ & 0.28 & $0-10$ & 0.35 & 0.22 \\
\hline & $10-30$ & 0.91 & $0-30$ & 1.26 & 0.64 \\
\hline & $30-50$ & 1.05 & $0-50$ & 2.31 & 0.95 \\
\hline \multirow[t]{2}{*}{ Permafrost } & $50-75$ & 1.20 & $0-75$ & 3.51 & 1.22 \\
\hline & $75-100$ & 1.30 & $0-100$ & 4.81 & 1.47 \\
\hline \multirow[t]{2}{*}{ B } & \multicolumn{5}{|c|}{ Active Floodplain Levels area: $8830 \mathrm{~km}^{2}$} \\
\hline & $\begin{array}{r}\text { Soil depth } \\
(\mathrm{cm})\end{array}$ & $\begin{array}{r}\text { Mass }_{\mathrm{h}} \\
(\mathrm{Tg})\end{array}$ & $\begin{array}{r}\text { Soil depth } \\
(\mathrm{cm})\end{array}$ & $\begin{array}{r}\operatorname{Mass}_{\mathrm{i}} \\
(\mathrm{Tg})\end{array}$ & $\begin{array}{r}\mathrm{SD} \\
(\mathrm{Tg})\end{array}$ \\
\hline \multirow{4}{*}{$\begin{array}{l}\text { Seasonally } \\
\text { thawed soil }\end{array}$} & $0-2$ & 0.14 & $0-2$ & 0.14 & 0.08 \\
\hline & $2-10$ & 0.73 & $0-10$ & 0.87 & 0.48 \\
\hline & $10-30$ & 1.79 & $0-30$ & 2.66 & 1.32 \\
\hline & $30-50$ & 1.46 & $0-50$ & 4.12 & 1.81 \\
\hline \multirow[t]{2}{*}{ Permafrost } & $50-75$ & 1.84 & $0-75$ & 5.96 & 2.54 \\
\hline & $75-100$ & 1.77 & $0-100$ & 7.73 & 3.55 \\
\hline
\end{tabular}


Generally, the considerable differences in the reported stocks of SOC originate in the strong spatial variability of soils on multiple scales. On the one hand, difficult access to remote permafrost-affected areas leads to an inhomogeneous distribution of investigation sites. On the other hand, large spatial heterogeneity within the same biome results in wide ranges and uncertainties, as well as questions of representativeness, of stock estimates and demonstrates the importance of intensive field work to produce more robust stock estimates and more representative data coverage. Besides the non-satisfying distribution of the soil cores across the investigation area, the low number of samples ( 29 soil cores with 6 subsamples each) play a large role for the uncertainty of the presented results. Additionally the way of (sub)sampling can be a source of uncertainties as reported in the method section. Due to logistical limits for sample weight for the present publication, only preselected parts of the soil cores could be analysed implying the need of estimation of the vertical distribution of the properties of the unsampled parts. The way of subsampling the same preselected depth in all sampled soil cores probably leads to biased results for single cores. Using this method assumed "organic rich" or "organic poor" layers could be missed in single cores. However, using the averaged results of several cores is expected to reduce this uncertainty.

\subsection{Soil organic carbon storage in the patterned ground and the soil subgroups}

Our estimates for the two characteristic microforms of the polygonal landscape, the polygon centres and polygon rims demonstrated a high micro-scale variability of the SOC stock within the investigated area. The mean $S_{\mathrm{OC}}(100 \mathrm{~cm})$ were $33.3 \mathrm{~kg} \mathrm{~m}^{-2} \pm 9.7 \mathrm{~kg} \mathrm{~m}^{-2}$ and $19.4 \mathrm{~kg} \mathrm{~m}^{-2} \pm 3.7 \mathrm{~kg} \mathrm{~m}^{-2}$ for polygon centres and rims, respectively. The polygons within the investigated area typically are about $15 \mathrm{~m}$ wide.

Analyzing the $S_{\mathrm{OC}}(100 \mathrm{~cm})$ on the soil subgroup level provided stock estimates ranging from $15.2 \mathrm{~kg} \mathrm{~m}^{-2} \pm 4.6 \mathrm{~kg} \mathrm{~m}^{-2}$ to $32.7 \mathrm{~kg} \mathrm{~m}^{-2} \pm 10.4 \mathrm{~kg} \mathrm{~m}^{-2}$. We, therefore, suggest that not only the SOC heterogeneity on the tundra biome scale needs to be captured in upscaling studies, but that more detailed field work is necessary to characterise site-scale SOC stock variations and how these may be successfully translated in upscaling approaches.

\subsection{Vertical distribution of the soil organic carbon storage within the soil}

Vertical distribution of carbon contents considerably differed between the two investigated geomorphic units. The volumetric organic carbon contents in the soils of the Holocene river terrace were rather uniformly distributed over the profiles' depths whereas volumetric carbon contents in the soils of the floodplains were clearly highest in the uppermost $10 \mathrm{~cm}$ from the soil surface. This latter pattern probably is caused by the ongoing regular flooding events of the plains.
On the one hand, the floods bring allochthonous organic matter, which is deposited with the alluvium on the floodplains. On the other hand, the growing vegetation, which is regularly covered by the alluvium, is incorporated in the upper soil horizons.

High intensity of flooding including sometimes strong water currents moving over the flat plains located near the river shore prevents plant growth resulting in low volumetric soil organic carbon contents. When a certain elevation of the floodplains is reached caused by regular sedimentation, the intensity of flooding and current of water will decrease and, therefore, plants will be able to establish. This sparse vegetation at the elevated floodplain sites is only flooded periodically. As a consequence of these flooding events, the vegetation is covered by a fresh sediment layer which hinders the continuation of plant growth. These sediment layers are then populated by a new generation of plants and incorporate the prior canopy as peat into the top soil horizons resulting in high contents of carbon in the upper parts of soil horizons.

\subsection{Permafrost soil organic carbon storage}

We assigned estimated SOC stock data to the landscape units of Samoylov Island, averaged them by land unit and estimated the SOC pool size within the respective geomorphic unit for the whole Lena River Delta by multiplying with the area of the corresponding unit, particularly the areas of the Holocene river terrace and the active floodplains derived from our satellite image classification. Our estimates indicate that the Lena River Delta contains in total $241 \mathrm{Tg}$ of SOC in the upper $1 \mathrm{~m}$ of soils within its river terrace and active floodplains. The SOC stock of the area-dominating active floodplains levels is $120 \mathrm{Tg} \pm 66 \mathrm{Tg}$. Despite covering only about half as much area as the active floodplains, soils of the Holocene river terrace have a similar sized total SOC stock of $121 \mathrm{Tg} \pm 43 \mathrm{Tg}$. About one half of the estimated SOC stock of these two morphological units $(127 \mathrm{Tg}$ ) occurs in the depth $0-50 \mathrm{~cm}$ which is the currently observed seasonal thaw depth in late summer. The organic carbon pool in the seasonally thawed top soil layer is subject to comparatively active decomposition and mineralization processes resulting in trace gas release to the atmosphere. On the other hand, this carbon pool gets also carbon inputs by fresh litter from the vegetation. First results of Höfle et al. (2012) indicate that physical protection mechanisms can limit SOC decomposition in the active layer.

The other portion of $113 \mathrm{Tg}$ SOC (ca. $47 \%$ ) in the depth from $50-100 \mathrm{~cm}$ is currently excluded from intense soilatmosphere exchange processes in the perennially frozen ground. Permafrost degradation resulting from higher temperatures and changed precipitation patterns leading to a deepening of the active layer are projected by global climate-permafrost models (Sazonova et al., 2004; Koven et al., 2011). The organic matter in the permafrost has been reported to be highly vulnerable to decay, and it is assumed 
that it has so far not undergone significant changes due to decomposition (Dutta et al., 2006; Khvorostyanov et al., 2008; Schuur et al., 2008, 2009; Waldrop et al., 2010). However, Knoblauch et al. (2013) argued that predictions of permafrost organic matter vulnerability are probably overestimated because typically too much carbon has been assigned to the fast-cycling SOC pool. It is expected that portions of the near-surface permafrost will disappear by the end of this century (Lawrence et al., 2008). For large areas of the Lena River Delta the thickness of the seasonally thawed layer is expected to increase to $120 \mathrm{~cm}$ and for some areas even to $180 \mathrm{~cm}$ by the end of this century (Sazonova et al., 2004).

With the help of the Northern Circumpolar Soil Carbon Database (see Hugelius et al., 2013), we calculated a SOC pool for the whole Lena River Delta and the depth of 0$100 \mathrm{~cm}$ of $670 \mathrm{Tg}$ carbon. When excluding the non-deltaic units, the SOC pool for the Holocene river terrace and the active floodplains was estimated to store around $357 \mathrm{Tg}$ carbon in the depth of $0-100 \mathrm{~cm}$. However, due to the given character of the database, we were neither able to exclude water bodies in the same way as done with our satellite imagery nor reduce the extent of the Holocene river terrace by the percentage of small water ponds and trough. Our reported carbon pool is lower with $241 \mathrm{Tg}$ which might be an effect of the reduced spatial extent of the Holocene river terrace and the active floodplains we used for the upscaling. For robust estimates of the SOC pool in the circumpolar-arctic delta regions sampling must be performed in other major river deltas of this region.

\subsection{Nitrogen stocks}

The mean $\mathrm{N}$ stock estimate for the investigation area and the depth of $100 \mathrm{~cm} S_{\mathrm{N}}(100 \mathrm{~cm})$ amounted to $1.1 \mathrm{~kg} \mathrm{~m}^{-2}$ or to $0.9 \mathrm{~kg} \mathrm{~m}^{-2}$ and $1.2 \mathrm{~kg} \mathrm{~m}^{-2}$, respectively, when the active floodplains and the river terrace are separately regarded. Jonasson et al. (1999) reported a N stock for arctic Scandinavian heath of $0.115 \mathrm{~kg} \mathrm{~m}^{-2}$ and a depth of $15 \mathrm{~cm}$, which theoretically can be recalculated for $100 \mathrm{~cm}$ depth amounting to $0.8 \mathrm{~kg} \mathrm{~m}^{-2}$. For the eroding Alaska Beaufort Sea coastline, Ping et al. (2011) reported an average total $\mathrm{N}$ storage of $1.4 \mathrm{~kg} \mathrm{~m}^{-2}$. The $\mathrm{N}$ stocks published by Harden et al. (2012) for $300 \mathrm{~cm}$ deep soil profiles of Gelisols were $4.6-7.5 \mathrm{~kg} \mathrm{~m}^{-2}$. Assuming a homogeneous vertical $\mathrm{N}$ stock distribution, the $S_{\mathrm{N}}(100 \mathrm{~cm})$ can be estimated at $1.5-$ $2.5 \mathrm{~kg} \mathrm{~m}^{-2}$ which is distinctly higher than the estimates of $S_{\mathrm{N}}$ $(100 \mathrm{~cm})$ in the Lena River Delta. The $S_{\mathrm{N}}(100 \mathrm{~cm})$ found in our study was in the range of the stock estimates of Jonasson et al. (1999) and Ping et al. (2011).

Our estimates indicate that the Lena River Delta contains $12.5 \mathrm{Tg}$ of $\mathrm{N}$ in the upper $1 \mathrm{~m}$ of soils within its Holocene river terrace and the active floodplain levels - reflecting a $\mathrm{C} / \mathrm{N}$ ratio of about 20 (compare Table 4). About $49 \%$ of this $\mathrm{N}$ pool is not available for soil-vegetation- atmosphere interactions due to permanent fixation in the perennially frozen ground.

An increased deepening of the seasonally thawed layer (Sazonova et al., 2004; Koven et al., 2011) is likely to make this frozen storage of $\mathrm{N}$ better available to soil microorganisms. As a limiting nutrient for plant productivity, this additionally released $\mathrm{N}$ is likely to enhance the net primary production of existing vegetation by reducing the general $\mathrm{N}$ limitation of tundra plant communities (Shaver et al., 1986; Schimel et al., 1996; Weintraub and Schimel, 2003) or triggering a general change of species composition. However, it has to be considered that the portion of directly plantavailable $\mathrm{N}$ within the amount of total $\mathrm{N}$ in soils is little as most $\mathrm{N}$ is contained in slow-cycling soil organic matter (Keuper et al., 2012).

\section{Conclusions}

The Lena River Delta, the largest arctic delta extends over an area of $32000 \mathrm{~km}^{2}$. We investigated SOC stocks of the Holocene river terrace and the active floodplain levels. Both together are the dominating geomorphic units in the Lena River Delta by area (62\% of the soil-covered area). The mean SOC stocks in the Holocene river terrace and the active floodplain are estimated at $29.5 \mathrm{~kg} \mathrm{~m}^{-2}$ and at $13.6 \mathrm{~kg} \mathrm{~m}^{-2}$, respectively. The Holocene river terrace stores about $50 \%$ of the estimated SOC stock while occupying $32 \%$ of the investigated portion of the Lena River Delta. Approximately $127 \mathrm{Tg}$ of the estimated SOC mass of the river terrace and the active floodplains are stored in the seasonally thawed layer $(0-50 \mathrm{~cm}$ depth). The SOC stock stored in permafrost $(50-$ $100 \mathrm{~cm}$ ) and currently excluded from intense biogeochemical exchange with the atmosphere accounts for $113 \mathrm{Tg}$. Taking into account the projections for deepening of the seasonally thawed active layer and general degradation of permafrost over this century, this large stock is likely to become increasingly available for decomposition and mineralization processes as well as fluvial retransportation and offshore/onshore deposition in the future. With our study, we showed that the SOC stock in the Lena River Delta is high compared to average values reported for the tundra. However, the stocks are not as high as reported in the Northern Circumpolar Soil Carbon Database (see Hugelius et al., 2013) for the depth of $0-1 \mathrm{~m}$, indicating that the total carbon storage in permafrost and the seasonally thawed layer of Arctic river deltas is probably lower than previously estimated, though still of substantial size. Here we investigated only the Holocene river terrace and active floodplain levels, and further complimentary investigations of the other geomorphic terraces that differ in cryostratigraphic composition and soils will be needed. In addition, we provide a first estimate of the total $\mathrm{N}$ stocks in this arctic river delta for the two investigated geomorphic units - the Holocene river terrace and the active floodplain levels - and the $\mathrm{N}$ pool sizes for the soils up to $100 \mathrm{~cm}$ in 
the corresponding geomorphic units. We also report the $\mathrm{N}$ stocks on soil subgroup level with their depth distribution. With a mean of $13 \mathrm{Tg}$, the $\mathrm{N}$ stocks are higher than would be expected by assuming a general $\mathrm{C} / \mathrm{N}$ ratio of 30 (Jonasson et al., 1999; Weintraub and Schimel, 2003) and considering our estimated SOC storage of $241 \mathrm{Tg}$. Though not investigated in detail within our investigation area, this large $\mathrm{N}$ pool deserves more consideration in future, particularly with regard to stocks of ammonium, nitrate and dissolved organic nitrogen.

Acknowledgement. This study was supported through the Cluster of Excellence "CliSAP" (EXC177), University of Hamburg, funded through the German Research Foundation (DFG). Sebastian Zubrzycki was supported by a dissertation fellowship funded through the University of Hamburg (HmbNFG) and a grant founded through the German Academic Exchange Service "DAAD" PKZ: D/10/01863. Guido Grosse was supported by NASA grant NNX08AJ37G and NSF OPP-0732735 and received WorldView-1 imagery through the Polar Geospatial Center at University of Minnesota.

The authors thank the Lena River Delta Reserve, especially Aleksander Gukov for the possibility to perform the study within the nature reserve. We thank the Alfred-Wegener-Institute in Potsdam and the "Hydro-Base" in Tiksi for logistical support. Special thanks go to Dmitri Bolshiyanov from the Arctic and Antarctic Research Institute, Irina Federova and Vladimir Churun from the Otto-Schmidt-Laboratory in St. Petersburg for using their laboratory facilities and help.

Edited by: I. Bussmann

\section{References}

Akhmadeeva, I., Becker, H., Friedrich, K., Wagner, D., Pfeiffer, E.M., Quass, W., Zhurbenko, M., and Zöller, E.: Investigation site "Samoylov", Rep. Polar Marine Res., 315, 19-21, 1999.

ArcGIS Resource Center. Desktop 10. An overview of the Spatial Analyst Toolbox: available at: http://help.arcgis.com/en/ arcgisdesktop/10.0/help/index.html\#//009z00000003000000. htm, last access: 5 October 2012.

Are, F. and Reimnitz, E.: An overview of the Lena River Delta setting: geology, tectonics, geomorphology, and hydrology, J. Coast. Res., 16, 1083-1093, 2000.

Bliss, N. B. and Maursetter, J.: Soil organic carbon stocks in Alaska estimated with spatial and pedon data, Soil Sci. Soc. Am. J., 74, 565-579, 2010.

Boike, J., Kattenstroth, B., Abramova, K., Bornemann, N., Chetverova, A., Fedorova, I., Fröb, K., Grigoriev, M., Grüber, M., Kutzbach, L., Langer, M., Minke, M., Muster, S., Piel, K., Pfeiffer, E.-M., Stoof, G., Westermann, S., Wischnewski, K., Wille, C., and Hubberten, H.-W.: Baseline characteristics of climate, permafrost and land cover from a new permafrost observatory in the Lena River Delta, Siberia (1998-2011), Biogeosciences, 10, 2105-2128, doi:10.5194/bg-10-2105-2013, 2013.
Chestnyck, O. V., Zamolodchikov, D. G., and Karelin, D. V.: Organic matter reserves in the soils of tundra and forest-tundra ecosystems of Russia, Ecologia, 6, 426-432, 1999 (in Russian).

Congalton, R.: A Review of Assessing the Accuracy of Classifications of Remotely Sensed Data, Remote Sens. Environ., 37, 35-46, 1991.

Dutta, K., Schuur, E. A. G., Neff, J. C., and Zimov, S. A.: Potential carbon release from permafrost soils of Northeastern Siberia, Glob. Change Biol., 12, 2336-2351, 2006.

Fiedler, S., Wagner, D., Kutzbach, L., and Pfeiffer, E.-M.: Element redistribution along hydraulic and redox gradients of lowcentered polygons, Lena-Delta, northern Siberia, Soil Sci. Soc. Am. J., 68, 1002-1011, 2004.

French, H. M.: The Periglacial Environment, John Wiley \& Sons Ltd, West Sussex, 458 pp., 2007.

Gorham, E., Lehman, C., Dyke, A., Janssens, J., and Dyke, L.: Temporal and spatial aspects of peatland initiation following deglaciation in North America, Quaternary Sci. Rev., 26, 300311, doi:10.1016/j.quascirev.2006.08.008, 2007.

Grigoriev, M. N.: The temperature of permafrost in the Lena delta basin - deposit conditions and properties of the permafrost in Yakutia, Yakustk, 2, 97-101, 1960 (in Russian).

Grigoriev, M. N.: Criomorphogenesis in the Lena Delta, Permafrost Institute Press, Yakutsk, 176 pp., 1993 (in Russian).

Grosse, G., Harden, J., Turetsky, M., McGuire, A. D., Camill, P., Tarnocai, C., Frolking, S., Schuur, E., Jorgenson, T., Marchenko, S., Romanovsky, V., Wickland, K. P., French, N., Waldrop, M., Bourgeau-Chavez, L., and Striegl, R. G.: Vulnerability of high-latitude soil organic carbon in North America to disturbance, J. Geophys. Res., 116, G00K06, doi:10.1029/2010JG001507, 2011

Gundelwein, A., Müller-Lupp, T., Sommerkorn, M., Haupt, E. T., Pfeiffer, E.-M., and Wiechmann, H.: Carbon in tundra soils in the Lake Labaz region of Arctic Siberia, Eur. J. Soil Sci., 58, 1164-1174, doi:10.1111/j.1365-2389.2007.00908.x, 2007.

Harden, J. W., Sundquist, E. T., Stallard, R. F., and Mark, R. K.: Dynamics of soil carbon during the deglaciation of the Laurentide ice sheet, Science, 258, 1921-1924, doi:10.1126/science.258.5090.1921, 1992.

Harden, J. W., Koven, C. D., Ping, C.-L., Hugelius, G., McGuire, A. D., Camill, P., Jorgenson, T., Kuhry, P., Michaelson, G. J., O’Donnell, J. A., Schuur, E. A. G., Tarnocai, C., Johnson, K., and Grosse, G.: Field information links permafrost carbon to physical vulnerabilities of thawing, Geophys. Res. Lett., 39, L15704, doi:10.1029/2012GL051958, 2012.

Höfle, S., Rethemeyer, J., Mueller, C. W., and John, S.: Organic matter composition and stabilization in a polygonal tundra soil of the Lena Delta, Biogeosciences, 10, 3145-3158, doi:10.5194/bg10-3145-2013, 2013.

Hugelius, G. and Kuhry, P.: Landscape partitioning and environmental gradient analyses of soil organic carbon in a permafrost environment, Global Biogeochem. Cy., 23, GB3006, doi:10.1029/2008GB003419, 2009.

Hugelius, G., Kuhry, P., Tarnocai, C., and Virtanen, T.: Soil Organic Carbon Pools in a Periglacial Landscape: a Case Study from the Central Canadian Arctic, Perma. Peri. Proc., 21, 16-29, 2010.

Hugelius, G., Virtanen, T., Kaverin, D., Pastukhov, A., Rivkin, F., Marchenko, S., Romanovsky, V., and Kuhry, P.: High-resolution mapping of ecosystem carbon storage and potential ef- 
fects of permafrost thaw in periglacial terrain, European Russian Arctic, J. Geophys. Res.-Biogeosci., 116, G03024, doi:10.1029/2011JG001730, 2011.

Hugelius, G., Tarnocai, C., Broll, G., Canadell, J. G., Kuhry, P., and Swanson, D. K.: The Northern Circumpolar Soil Carbon Database: spatially distributed datasets of soil coverage and soil carbon storage in the northern permafrost regions, Earth Syst. Sci. Data, 5, 3-13, doi:10.5194/essd-5-3-2013, 2013

IPCC - Intergovernmental Panel on Climate Change: Climate Change 2007 - IPCC Fourth Assessment Report, Cambridge University Press, Cambridge, United Kingdom and New York, NY, USA, 2007.

ISO 10694: Soil quality - Determination of organic and total carbon after dry combustion (elementary analysis), 1995.

Jonasson, S., Michelsen, A., and Schmidt, I. K.: Coupling of nutrient cycling and carbon dynamics in the Arctic, integration of soil microbial and plant processes, Appl. Soil Ecol., 11, 135-146, 1999.

Jones, A., Stolbovoy, V., Tarnocai, C., Broll, G., Spaargaren, O., and Montanarella, L.: Soil Atlas of the Northern Circumpolar Region, European Commission, Publications Office of the European Union, Luxembourg, 144 pp., 2010.

Keuper, F., van Bodegom, P. M., Dorrepaal, E., Weedon J. T., van Hal, J., van Logtestijn, R. S. P., and Aerts, R.: A frozen feast: thawing permafrost increases plant-available nitrogen in subarctic peatlands, Global Change Biol., 18, 6, 1998-2007, 2012.

Khvorostyanov, D. V., Krinner, G., and Ciais, P.: Vulnerability of permafrost carbon to global warming, Part I. Model description and role of heat generated by organic matter decomposition, Tellus B, 60, 343-358, 2008.

Knoblauch, C., Beer, C., Sosnin, A., Wagner, D. and Pfeiffer, E.-M.: Predicting long-term carbon mineralization and trace gas production from thawing permafrost of Northeast Siberia, Global Change Biol., 19, 1160-1172, doi:10.1111/gcb.12116, 2013.

Kolchugina, T. P., Vinston, T. S., Gaston, G. G. Rozhkov, V. A., and Shwidenko, A. Z.: Carbon pools, fluxes and sequestration potential in soils of the former Soviet Union, in: Soil Management and Greenhouse Effect, edited by: Lal, R., Kimble, J., Levine, E., and Stewart, B. A., Lewis, Boca Raton, FL, 25-40, 1995.

Koven, C. D., Ringeval, B., Friedlingstein, P., Ciais, P., Cadule, P., Khvorostyanov, D., Krinner, G., and Tarnocai, C.: Permafrost carbon-climate feedbacks accelerate global warming, Proc. Natl. Acad. Sci., 108, 14769-14774, 2011.

Kutzbach, L.: The exchange of energy, water and carbon dioxide between wet arctic tundra and the atmosphere at the Lena River Delta, Northern Siberia, Rep. Polar Marine Res., 541, 141 pp., 2006.

Kutzbach, L., Wagner, D., and Pfeiffer, E.-M.: Effect of microrelief and vegetation on methane emission from wet polygonal tundra, Lena-Delta, Northern Siberia, Biogeochemistry, 69, 341362, 2004.

Lawrence, D. M., Slater, A. G., Romanovsky, V. E., and Nicolsky, G. J.: Sensitivity of a model projection of near-surface permafrost degradation to soil column depth and representation of soil organic matter, J. Geophys. Res., 113, F02011, doi:10.1029/2007JF000883, 2008.

Loveland, T. R., Reed, B. C., Brown, J. F., Ohlen, D. O., Zhu, Z., Yang, L., and Merchant, J. W.: Development of a global land cover characteristics database and IGBP DISCover from $1 \mathrm{~km}$
AVHRR data, Int. J. Remote Sens., 21, 1303-1330, 2000.

Matsuura, Y. and Yefremov, D. P.: Carbon and nitrogen storage of soils in a forest-tundra area of Northern Sakha, Russia, in: Proceedings of the Third Symposium on the Joint Siberian Permafrost Studies between Japan and Russia in 1994, 97-101, Forest \& Forest Products Research Unit, University of Sapporo, Sapporo, Japan, 1995.

Morgenstern, A., Grosse, G., and Schirrmeister, L.: Genetic, morphological, and statistical characterisation of lakes in the permafrost-dominated Lena Delta, in: Proceedings of the 9th International Conference on Permafrost, edited by: Kane, D. L. and Hinkel, K. M., Institute of Northern Engineering, University of Alaska, Fairbanks, 1239-1244, 2008.

Morgenstern, A., Grosse, G., Günther, F., Fedorova, I., and Schirrmeister, L.: Spatial analyses of thermokarst lakes and basins in Yedoma landscapes of the Lena Delta, The Cryosphere, 5, 849-867, doi:10.5194/tc-5-849-2011, 2011.

Pavlova, E. and Dorozhkina, M.: Geological-geomorphological studies in the northern Lena River Delta, Rep. Polar Marine Res., 315, 112-126, 1999.

Pfeiffer, E.-M., Wagner, D., Becker, H., Vlasenko, A., Kutzbach, L., Boike, J., Quass, W., Kloss, W., Schulz, B., Kurchatova, A., Pozdnyakov, V., and Akhmadeeva, I.: Modern processes in permafrost affected soils, Rep. Polar Marine Res., 354, 22-54, 2000.

Pfeiffer, E.-M., Wagner, D., Kobabe, S., Kutzbach, L., Kurchatova, A., Stoof, G., and Wille, C.: Modern processes in permafrost affected soils, Rep. Polar Marine Res., 426, 21-41, 2002.

Ping, C. L., Michaelson, G. J., Jorgenson, M. T., Kimble, J. M., Epstein, H., Romanovsky, V. E., and Walker, D. A.: High stocks of soil organic carbon in the North American Arctic region, Nature Geosci., 1, 615-619, 2008.

Ping, C.-L., Michaelson, G. J., Guo, L., Jorgenson, M. T., Kanevskiy, M., Shur, Y., Dou, F., and Liang, J.: Soil carbon and material fluxes across the eroding Alaska Beaufort Sea coastline, J. Geophys. Res. 116, G02004, doi:10.1029/2010JG001588, 2011.

Post, W. M., Emanuel, W. R., Zinke, P. J., and Stangenberger, A. G.: Soil carbon pools and world life zones, Nature, 298, 156-159, 1982.

Romanovsky, V. E., Drozdov, D. S., Oberman, N. G., Malkova, G. V., Kholodov, A. L., Marchenko, S. S., Moskalenko, N. G., Sergeev, D. O., Ukraintseva, N. G., Abramov, A. A., Gilichinsky, D. A., and Vasiliev, A. A.: Thermal state of permafrost in Russia, Perma. Peri. Proc., 21, 136-155, 2010.

Roshydromet: Russian Federal Service for Hydrometeorology and Environmental Monitoring, available at: http://www. worldweather.org, last access: 8 August 2011.

Sachs, T., Giebels, M., Boike, J., and Kutzbach, L.: Environmental controls on $\mathrm{CH}_{4}$ emission from polygonal tundra on the microsite scale in the Lena River Delta, Siberia, Global Change Biol., 16, 3096-3110. doi:10.1111/j.1365-2486.2010.02232.x, 2010.

Sanders, T., Fiencke, C., and Pfeiffer, E.-M.: Small-scale variability of dissolved inorganic nitrogen (DIN), C/ $\mathrm{N}$ ratios and ammonia oxidizing capacities in various permafrost affected soils of Samoylov Island, Lena River Delta, Northeast Siberia, Polarforschung, 80, 23-35, 2010.

Sazonova, T. S., Romanovsky, V. E., Walsh, J. E., and Sergueev, D. O.: Permafrost dynamics in the 20th and 21 st centuries along the East Siberian transect, J. Geophys. Res., 109, D01108, 
doi:10.1029/2003JD003680, 2004.

Schaefer, K., Zhang, T. J., Bruhwiler, L., and Barrett, A. P.: Amount and timing of permafrost carbon release in response to climate warming, Tellus B, 63, 165-180, doi:10.1111/j.16000889.2011.00527.x, 2011.

Schimel, J. P., Reynolds, J. F., Tenhunen, J. D., Kielland, K., and Chapin III, F. S.: Nutrient availability and uptake by tundra plants, in: Ecological Studies Analysis and Synthesis, vol. 120: Landscape Function and Disturbance in Arctic Tundra, SpringerVerlag, New York, 203-221, 1996.

Schirrmeister, L., Grosse, G., Wetterich, S., Overduin, P. P., Strauss, J., Schuur, E. A. G., and Hubberten, H.-W.: Fossil organic matter characteristics in permafrost deposits of the northeast Siberian Arctic, J. Geophys. Res., 116, G00M02, doi:10.1029/2011JG001647, 2011.

Schneider, J., Grosse, G., and Wagner, D.: Land cover classification of tundra environments in the Arctic Lena Delta based on Landsat 7 ETM+ data and its application for upscaling of methane emissions, Remote Sens. Environ., 113, 380-391, 2009.

Schuur, E., Bockheim, J., Canadell, J., Euskirchen, E., Field, C., and Goryachkin, S.: Vulnerability of permafrost carbon to climate change: implications for the global carbon cycle, Bioscience, 58, 701-714, 2008.

Schuur, E., Vogel, J., Crummer, K., Lee, H., Sickman, J., and Osterkamp, T.: The effect of permafrost thaw on old carbon release and net carbon exchange from tundra, Nature, 459, 556-559, 2009.

Schwamborn, G., Rachold, V., and Grigoriev, M. N.: Late quaternary sedimentation history of the Lena Delta, Quaternary Int., 89, 119-134, 2002.

Shaver, G. R., Chapin III, F. S., and Gartner, B. L.: Factors limiting seasonal growth and peak biomass accumulation in Eriophorum vaginatum in Alaskan [USA] tussock tundra, J. Ecol., 74, 257278, 1986.

Smith, L. C., MacDonald, G. M., Velichko, A. A., Beilman, D. W., Borisova, O. K., Frey, K. E., Kremenetski, K. V., and Sheng, Y.: Siberian peatlands a net carbon sink and global methane source since the early Holocene, Science, 303, 353-356, doi:10.1126/science.1090553, 2004.

Soil Survey Staff: Keys to Soil Taxonomy, United States Department of Agriculture \& Natural Resources Conservation Service, Washington, D. C., 329 pp., 2010.

Stolbovoi, V.: Carbon in Russian soils, Climatic Change, 55, 131156, 2002.

Stolbovoi, V.: Soil carbon in the forests of Russia, Mitig. Adapt. Strategies Glob. Change, 11, 203-222, doi:10.1007/s11027-0061021-7, 2006.
Tarnocai, C., Kimble, J., and Broll, G.: Determining carbon stocks in Cryosols using the Northern and Mid Latitudes Soil Database, in: Permafrost, edited by: Philips, M., Springman, S., and Arenson, L. U., Vol. 2, A. A. Balkema Publishers, Swets \& Zeitlinger, Lisse, the Netherlands, 1129-1134, 2003.

Tarnocai, C., Canadell, J. G., Schuur, E. A. G., Kuhry, P., Mazhitova, G., and Zimov, S.: Soil organic carbon pools in the northern circumpolar permafrost region, Global Biogeochem. Cy., 23, GB2023, doi:10.1029/2008GB003327, 2009.

Ulrich, M., Grosse, G., Schirrmeister, L., and Chabrillat, S.: Spectral characterisation of periglacial surfaces and geomorphological units in the Arctic Lena Delta using field spectrometry and remote sensing, Remote Sens. Environ., 113, 1220-1235, 2009.

Wagner, D., Gattinger, A., Embacher, A., Pfeiffer, E.-M., Schloter, M., and Lipski, A.: Methanogenic activity and biomass in Holocene permafrost deposits of the Lena Delta, Siberian Arctic and its implication for the global methane budget, Global Change Biol., 13, 1089-1099, 2007.

Waldrop, M. P., Wickland, K. P., White III, R., Berhe, A. A., Harden, J. W., and Romanovsky, V.: Molecular investigations into a globally important carbon pool: permafrost-protected carbon in Alaskan soils, Glob. Change Biol., 16, 2543-2554, doi:10.1111/j.1365-2486.2009.02141.x, 2010.

Walker, H. J.: Arctic deltas, J. Coast. Res., 14, 718-738, 1998.

Weintraub, M. N. and Schimel, J. P.: Interactions between carbon and nitrogen mineralization and soil organic matter chemistry in arctic tundra soils, Ecosystems, 6, 129-143, 2003.

Yershov, E. D., Kondrat'yeva, K. A., Loginov, V. F., and Sychev, I. K.: Geocryological Map of Russia and Neighbouring Republics, Faculty of Geology, Chair of Geocryology, Lomonosov Moscow State University, Moscow, 1991.

Zimov, S. A., Davydov, S. P., Zimova, G. M., Davydova, A. I., Schuur, E. A. G., Dutta, K., and Chapin III, F. S.: Permafrost carbon: stock and decomposability of a globally significant carbon pool, Geophys. Res. Lett., 33, L20502,doi:10.1029/2006GL027484, 2006.

Zubrzycki, S.: Drilling frozen soils in Siberia, Polarforschung, 81, 151-153, 2012.

Zubrzycki, S., Kutzbach, L., and Pfeiffer, E.-M.: Böden in Permafrostgebieten der Arktis als Kohlenstoffsenke und Kohlenstoffquelle (Soils in arctic permafrost regions as carbon sink and source), Polarforschung, 81, 33-46, 2012. 